\title{
PADRÃO DE CONHECIMENTO DO ATLETA AMADOR DE BAURU-SP, RELACIONADO AOS CUIDADOS DE SAÚDE BUCAL
}
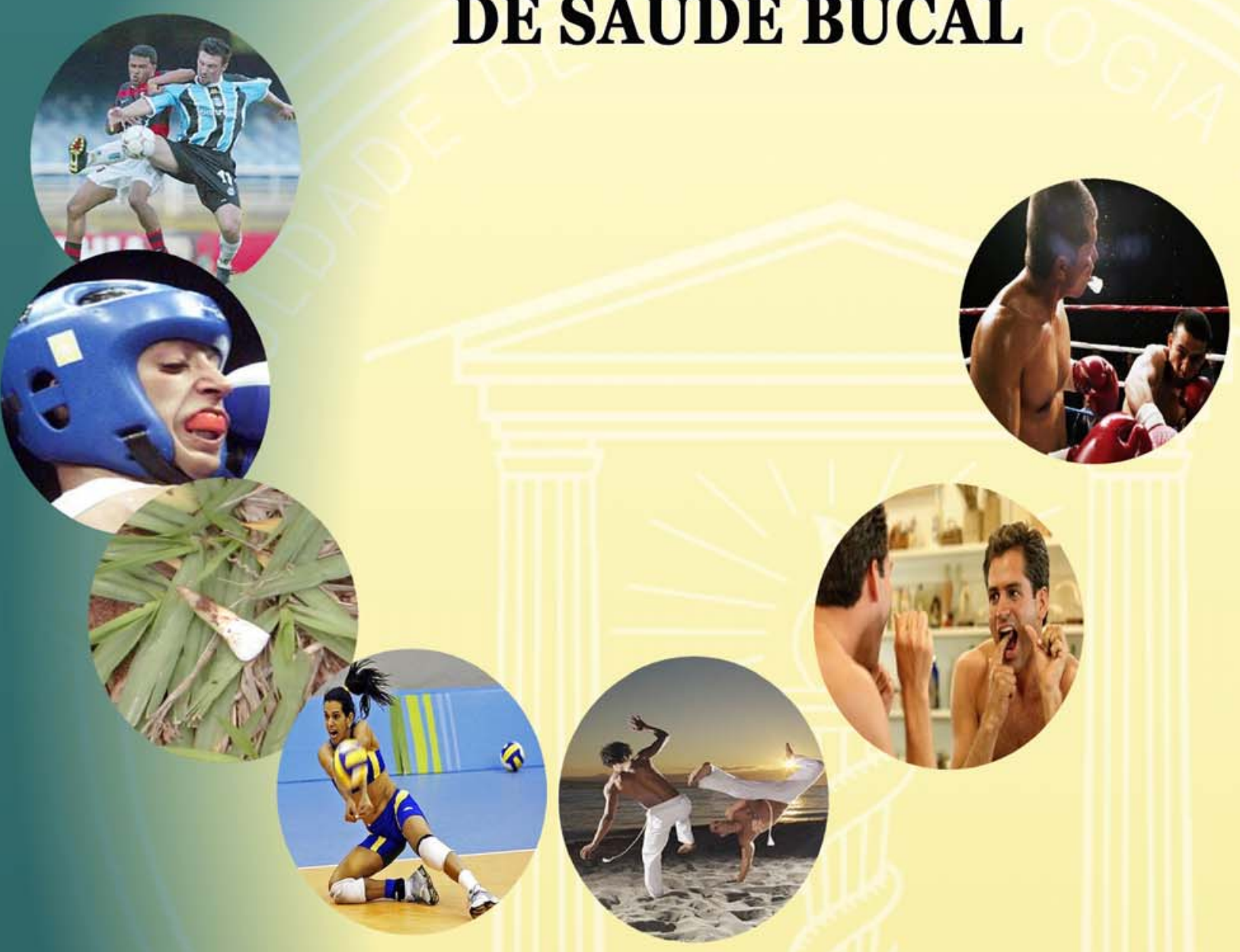

\section{Hilton José Gurgel Rodrigues}

Dissertação apresentada à Faculdade de Odontologia de Bauru da Universidade de São Paulo como parte dos requisitos para obtenção do título de Mestre em Odontologia, na área de Saúde Coletiva. 


\section{PADRÃO DE CONHECIMENTO \\ DO ATLETA AMADOR DE BAURU-SP, RELACIONADO AOS CUIDADOS DE SAÚDE BUCAL}

\section{Hilton J osé Gurgel Rodrigues}

Dissertação apresentada à Faculdade de Odontologia de Bauru, da Universidade de São Paulo, como parte dos requisitos para obtenção do título de Mestre em Odontologia, na área de Saúde Coletiva.

(Edição Revisada)

Orientador: Prof. Dr. José Roberto de Magalhães Bastos

BAURU 


\section{Universidade de São Paulo}

Faculdade de Odontologia de Bauru

Al. Dr. Octavio Pinheiro Brisolla. 9-75 - Bauru-SP - CEP 17012-901 - C.P. 73

PABX (OXX 14)235-8000 — FAX (0XX 14)223-4679

Pós-Graduação

e-mail: posgrad(a fob.usp.br — Fone: (OXX14)235-8223

FOLHA DE APROVAÇÃO

Dissertação apresentada e defendida por

HILTON JOSE GURGEL RODRIGUES

e aprovada pela Comissão Julgadora em 19 de maio de 2005.

Prof. Dr. ANTONIO CARLOS PEREIRA

Faculdade de Odontologia de Piracicaba - UNICAMP

Prof. Dr.

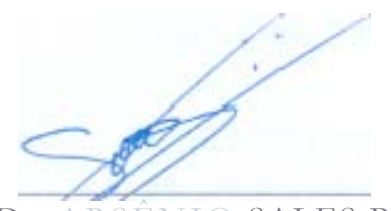

Faculdade de Odontologia de Bauru - USP

Prof. Dr. JOSE ROBERTO DE MAGALHÃES BASTOS

Presidente da Banca

Faculdade de Odontologia de Bauru - USP

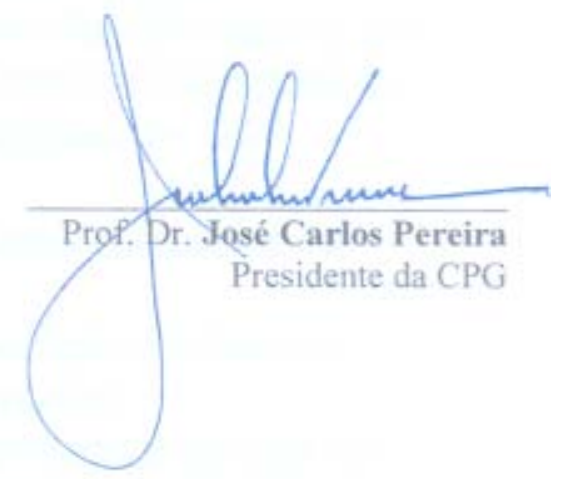




Rodrigues, Hilton José Gurgel
Padrão de conhecimento do atleta amador de Bauru
- SP, relacionado aos cuidados de saúde bucal / Hilton
José Gurgel Rodrigues. -- Bauru, 2005.
xviii, 128 p. : il. ; $30 \mathrm{~cm}$.
Dissertação $\quad$ (Mestrado) --- Faculdade de
Odontologia de Bauru. Universidade de São Paulo.
Orientador: Prof. Dr. José Roberto de Magalhães
Bastos

Autorizo, exclusivamente pra fins acadêmicos e científicos, a reprodução total ou parcial desta tese, por processos fotocopiadores e outros meios eletrônicos.

Assinatura do autor:

Data:

Comitê de Ética da FOB-USP

Protocolo n.: $62 / 2004$

Data: $04 / 10 / 2004$ 


\section{DADOS CURRICULARES}

\section{Hi lton J OSÉ GURGel ROdRI GUES}

15 de Outubro de 1971

$$
\text { Natal - RN }
$$

Filiação

$1997-2001$

2002

$2002-2003$

2004

$2003-2005$

Associações
Nascimento

Pedro Rodrigues da Silva

Maria da Soledade Gurgel Rodrigues

Graduação em Odontologia

Universidade Potiguar - UnP.

Curso de aperfeiçoamento em Endodontia na Associação Paulista de Cirurgiões Dentistas - APCD (Regional Bauru).

Curso de Especialização em Odontologia em Saúde Coletiva na Associação Paulista de Cirurgiões Dentistas - APCD (Regional Bauru).

Professor do Curso de Odontologia Desportiva na Faculdade de Odontologia da Universidade de São Paulo.

Curso de Pós-Graduação em Odontologia em Saúde Coletiva, em nível de Mestrado na Faculdade de Odontologia de Bauru - USP.

ABO - Associação Brasileira de Odontologia APOD - Associação Paulista de Cirurgiões Dentistas SBPqO - Sociedade Brasileira de Pesquisa Odontológica 


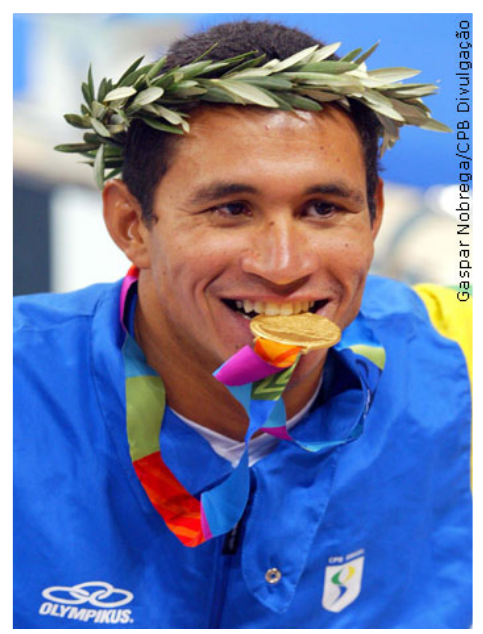

“Para ser um campeão é preciso acreditar em você mesmo.

mesmo quando ninguém acredita em você”.

Sugar Ray Leonard 


\section{DEDICO ESTE TRABALHO}

Aos meus pais Pedro Rodrigues da Silva e Maria da Soledade Gurgel Rodrigues, em quem sempre encontrei incentivo, apoio, amor e fé, e pelo muito que representam em minha vida.

À minha querida esposa Lidianne Christina Izaías de Oliveira Gurgel Rodrigues, pelo apoio, ternura, companheirismo, lágrimas e renuncia dedicadas a mim, principalmente pela sua compreensão e paciência, principalmente, no período que estive ausente realizando este trabalho. 


\section{A MINHA GRATIDÃO}

A Deus, que com sua infinita bondade me abençoou e iluminou o meu caminho, dando-me coragem para optar e sabedoria para escolher. Agradeço ao Senhor por me fazer uma pessoa autêntica, corajosa e fiel aos meus princípios. Tua palavra sempre foi e será minha fonte inesgotável de inspiração para vencer todas as etapas de vida. 
Aos tios Sérgio Rodrigues Fontes e Maria Solange Gurgel de Castro Fontes, ao primo Júlio Gurgel Fontes, minha família em Bauru, que me receberam como filho e irmão, contribuindo para amenizar a saudade dos familiares e da terra natal. 
Ao Prof. Dr. José Roberto de Magalhães Bastos, exemplo de humildade e dedicação, que além de transmitir conhecimentos, sempre me orientou como Pai, e vem me ajudando a enriquecer minha formação docente na sua plenitude e a crescer como profissional, possibilitando a concretização de um sonho tão almejado. 
A todos os meus familiares que me incentivaram, acreditaram e rezaram para mim.

Ao Sr. José Roberto Franco "Sapé", Ex-Secretário de Esportes e Lazer da cidade de Bauru, que como desportista apoiou incondicionalmente e abriu todas as portas necessárias para realização desta pesquisa.

A Faculdade de Odontologia de Bauru da Universidade de São Paulo, na pessoa de sua Diretora Prof ${ }^{\mathrm{a}}$ Dr $^{\mathrm{a}}$. Maria Fidela de Lima Navarro.

Ao Cirurgião-Dentista José Mauro de Castro Figliolia por me orientar e motivar a realizar este curso de mestrado.

Aos demais professores do Departamento de Odontologia em Saúde Coletiva da FOB-USP, Dr. Arsenio Sales Peres, Dr. José Roberto Pereira Lauris, $\mathrm{Dr}^{\mathrm{a}}$. Nilce Emy Tomita e Ms. Silvia Helena de Carvalho Sales Peres, pelo empenho e satisfação ao transmitirem seus conhecimentos.

Ao Professor Dr. Ernesto Pilotto Gomes de Medeiros, pelo incentivo e atenção em ensinar sua singular experiência científica.

À $\operatorname{Prof}^{\mathrm{a}} \operatorname{Dr}^{\mathrm{a}}$ Maria Aparecida de Andrade Moreira Machado, pelo carinho, atenção e paciência com que me transmitiu alguns de seus conhecimentos, que foram de grande importância para meu crescimento científico.

À Prof ${ }^{\mathrm{a}} \mathrm{Dr}^{\mathrm{a}}$ Lecy de Maria Araújo Gadelha Fernandes, Pró-Reitora de Pesquisa e Pós-Graduação da UnP - Universidade Potiguar, em Natal$\mathrm{RN}$, pelas palavras que me proporcionaram ânimo e novos pontos de referência para o meu desenvolvimento profissional. 
Aos Professores Antônio Júnior, Fátima Jorge, Lígia Moura, e Maria Alice, Docentes da disciplina de Cariologia e Odontologia Preventiva e Social, da Universidade Potiguar, por terem estimulado meu crescimento científico e o meu amor a Saúde Coletiva.

Ao Prof. Dr. Antônio Ricardo Calazans Duarte e família, pelo apoio, atenção, conselhos, carinho e por serem os amigos certos em todos os momentos deste período de mestrado.

Aos Doutores Noberto Francisco Lubiana (ABO Nacional), Celso Kenji (ABO Bauru), e José Alberto Silvestre (ABO Campinas) por terem aberto as portas das instituições por eles presididas para a divulgação da Odontologia Esportiva e a Saúde Coletiva.

Ao Professor Alexandre Fonseca Barberini (FOUSP) por ter me convidado a ser um dos professores do curso de Odontologia Desportiva da FUNDECTO, no ano de 2004.

Aos colegas de turma: Aline, Beatriz, Fabiano, Fabíola, Haroldo, Irene, Kelly, Lucilene, Priscila, Ricardo e Roberta, pelo carinho, incentivo e exemplo de cada um.

Às funcionárias Marta, Silvia, Rosa e Helena do Departamento de Saúde Coletiva da faculdade de Odontologia de Bauru, pela amizade, carinho, colaboração e apoio.

Aos amigos Paulo César Pereira, Wolber Arcoverde Fechini, Joab Nascimento, Fernando José, Sérgio Maia, Bruno Maia, Laurita Galvão, Flaviana Camelo pelo incentivo, alegria e amizade.

Às amigas Jovelina (Jove), Cleide, Josefina (Zefina), Antonieta, e Laura, aos casais: Manoel e Joice, Antônio Carlos e Kelly, Mitisuo e Vera, Marcos e Vânia, Maurício e Eliana, João e Delfina, João e Maria 
Alice, Régis e Célia, Jairo e Vera, Maércio e Érica, Parrom e Marilena, Rodrigo e Vanusa, pelo acolhimento, amizade, carinho, orações e momentos de grande alegria e tribulações para mim.

Ao amigo Rubens Kazuo Kato, Designer Gráfico da FOB-USP pelo desenho da capa deste trabalho.

Ao Cirujano Dentista Daniel Eduardo Bayardo González (México), aluno do Mestrado em Odontologia na Área de concentração Reabilitação Oral, pela valiosa colaboração en español.

Aos funcionários da Biblioteca da FOB-USP pela atenção e orientação.

A instituição de fomento CAPES pelo apoio financeiro.

A todos que, ao longo deste curso, fizeram parte do meu dia a dia, tornando este tempo inesquecível e me deram a certeza de que valeu a pena. 


\section{SUMÁRIO}

LISTA DE FIGURAS .............................................................. xiii

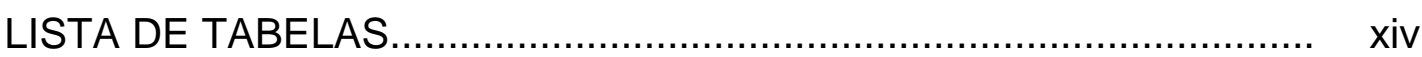

LISTA DE ABREVIATURAS ................................................. Xvii

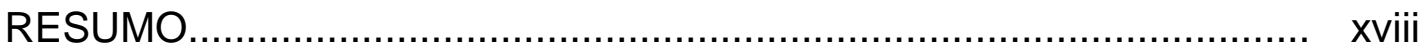

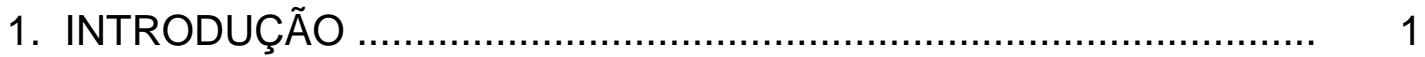

2. REVISÃO DA LITERATURA ............................................. 5

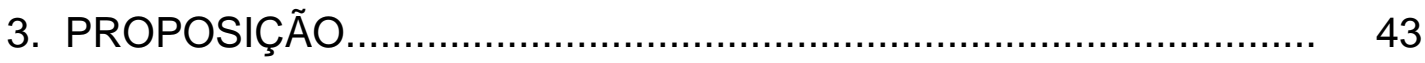

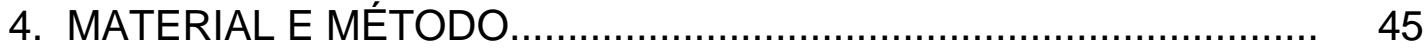

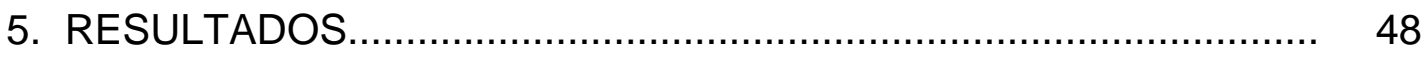

5.1 - Participação quanto ao gênero e esporte................................. 49

5.2 - Conhecimentos sobre protetores bucais................................. 51

5.3 - Higiene bucal do atleta.............................................. 59

5.4 - Relação Atleta / Cirurgião-Dentista...................................... 73

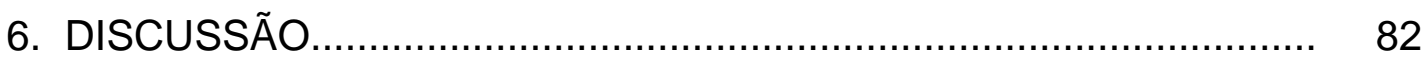

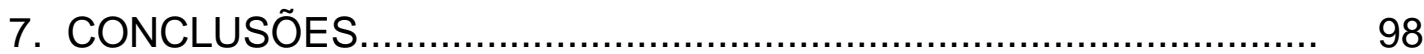

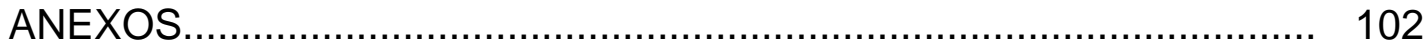

REFERÊNCIAS BIBLIOGRÁFICAS...................................... 110

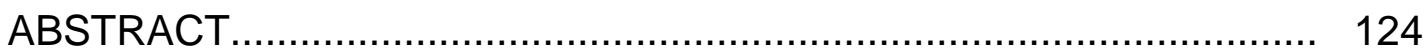

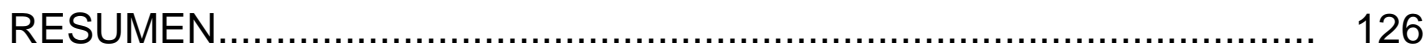




\section{LISTA DE FIGURAS}

FIGURA 1. Participação dos atletas quanto ao gênero

FIGURA 2. Participação dos atletas por esporte

50

FIGURA 3. Sofrimento de traumatismos dentários durante a prática esportiva.

FIGURA 4. Conhecimento dos atletas sobre protetores bucais.

FIGURA 5. Uso de protetores bucais pelos atletas que conhecem os protetores bucais

FIGURA 6. Uso de protetores bucais pelos os atletas que participaram da pesquisa

FIGURA 7. Tipo de protetor bucal utilizado pelos atletas.

FIGURA 8. Como foram adquiridos os protetores bucais 55

FIGURA 9. Uso de protetor bucal emprestado.

FIGURA 10. Falta a treinos, jogos ou competições devido a problemas dentários.

FIGURA 11. Opinião dos sujeitos da pesquisa, referente a uma boca com problemas poder prejudicar a capacidade do atleta. 


\section{LISTA DE TABELAS}

TABELA 1. Compartilhamento do mesmo creme dental entre atletas e seus familiares.

TABELA 2. Compra do creme dental pelo atleta. 59

TABELA 3. Quem compra o creme dental dos atletas. 60

TABELA 4. Uso freqüente do mesmo creme dental. 60

TABELA 5. Dentifrícios usados pelos atletas 61

TABELA 6. Principais motivos que levam o atleta escolher um dentifrício

TABELA 7. Número de vezes que os atletas escovam os dentes ao dia.

TABELA 8. Identificação de um dentifrício apenas pelo sabor.

TABELA 9. Número de atletas que fazem uso do fio dental

TABELA 10. Número de vezes que os atletas usam fio dental ao dia.. 64

TABELA 11. Justificativas pelo não uso do fio dental. 65

TABELA 12. Justificativas pelo não uso do fio dental (por esporte)....... 66

TABELA 13. Uso de bochechos pelos atletas 66 
TABELA 14. Uso de bochechos pelos atletas (por esporte).

TABELA 15. Número de vezes que os atletas usam o bochecho ao dia.

TABELA 16. Motivos pelos quais os atletas não usam o bochecho.....

TABELA 17. Quem compra as escovas de dentes dos atletas. 70

TABELA 18. Quem compra as escovas dentárias dos atletas que afirmaram não comprar sua escova.

TABELA 19. Cores da preferência para uma escova de dentes segundo os atletas

TABELA 20. Tipo de escova utilizada pelos atletas (quanto à dureza das cerdas).

TABELA 21. Período que um atleta usa uma escova de dentes

TABELA 22. Medo dos atletas de freqüentar a clínica odontológica....

TABELA 23. Medo de freqüentar a clínica odontológica (quanto ao gênero)

TABELA 24. Justificativas do medo dos atletas para com o CirurgiãoDentista.

TABELA 25. Justificativas dos atletas por não terem medo do Cirurgião-Dentista.

TABELA 26. Quem cuida dos dentes dos atletas 
TABELA 27. Justificativas dos atletas por não realizarem tratamento odontológico.

TABELA 28. Periodicidade das visitas dos atletas ao consultório odontológico.

TABELA 29. Periodicidade das visitas dos atletas ao consultório odontológico (por esporte)

TABELA 30. Principais motivos que levam os atletas ao consultório odontológico.

TABELA 31. Outros motivos que levam os atletas ao consultório odontológico.

TABELA 32. Recebimento de informações de um Cirurgião-Dentista sobre prevenção de traumatismos dentários. 80

TABELA 33. Importância dada pelos atletas quanto à presença de um Cirurgião-Dentista em seu clube. 


\section{LISTA DE ABREVIATURAS}

ABO - Associação Brasileira de Odontologia

ADA - American Dental Association

APCD - Associação Paulista de Cirurgiões-Dentistas

ASD - Academy for Sports Dentistry

ASTM - American Society for Testing and Materials

ATM - Articulação Temporomandibular

CBF - Confederação Brasileira de Futebol

CD - Cirurgião-Dentista

EUA - Estados Unidos da América

NCAA - National Collegiate Athletic Association

NYSSF - National Youth Sports Safety Foundation

OMS - Organização Mundial da Saúde

SEMEL - Secretaria Municipal de Esportes e Lazer de Bauru-SP

UNISA - Universidade de Santo Amaro

USP - Universidade de São Paulo 


\section{RESUMO}

O presente estudo teve o propósito de avaliar o padrão de conhecimento dos atletas amadores da cidade de Bauru-SP, relacionado aos cuidados de saúde bucal, tais como: prevenção de traumatismos dentários, escovação, uso do fio dental, dentifrícios mais utilizados, uso de bochechos e escovas dentais utilizadas. Além disso, também foram avaliados o hábito e a freqüência de consultas odontológicas, em serviço público ou privado. Um questionário foi elaborado e aplicado em uma amostra de 36 atletas, sendo 15 do gênero masculino e 21 do gênero feminino, todos membros de equipes amadoras assistidas pela SEMEL (Secretaria Municipal de Esporte e Lazer), das modalidades: boxe, capoeira, futebol e voleibol, com média de idade entre 16 e 28 anos. A análise dos resultados permitiu evidenciar que os atletas, mesmo sem os conhecimentos considerados ideais de higiene bucal e da relação saúde bucal com a saúde geral, em sua maioria são conscientes que uma boca com problemas pode prejudicar o desempenho do atleta e acham extremamente importante que haja um Cirurgião-Dentista em suas equipes acompanhando treinos, jogos e competições. Contudo, apenas 17\% dos atletas usam protetores bucais durante a prática esportiva, 64\% escovam os dentes 3 vezes ao dia, 50\% usam fio dental, 44\% realizam bochecho e $33 \%$ não vão à clínica odontológica, sendo a dor o principal fator que leva os esportistas a freqüentá-la. Estas constatações refletem uma realidade, não só local, mas brasileira, o que comprova a necessidade de uma conscientização das instituições de saúde, educação e esportivas, para que sejam feitas campanhas públicas na tentativa de estimular os praticantes de esportes e a comunidade em geral a uma melhor atenção aos cuidados de higiene bucal, a praticar esporte com segurança, utilizando protetores bucais, e ensinar os procedimentos imediatos frente a um traumatismo dentário. 
1 INTRODUÇÃO 


\section{INTRODUÇÃO}

Uma infecção na boca pode provocar muito mais do que dor na vida de um atleta. Ela pode ser responsável por problemas que acabem com a sua carreira, como a falta de fôlego e distensões. Um simples exame de rotina pode identificar problemas que podem prejudicar o desempenho dos jogadores em um momento crucial de um campeonato, sem citar que a presença de um Cirurgião-Dentista pode ser mais do que providencial para atendimentos de emergência, principalmente em um esporte de alto risco como o futebol.

Segundo dados da NATIONAL YOUTH SPORTS SAFETY FOUNDATION $^{59}$ (NYSSF), uma entidade de pesquisa norte-americana dedicada aos estudos e à prevenção de traumas esportivos, todo atleta envolvido numa atividade esportiva de contato físico tem até $10 \%$ de chance, durante uma temporada, de sofrer uma lesão facial e de 33 a 56\% de probabilidade de que uma lesão deste tipo ocorra em toda a sua carreira. $\mathrm{O}$ que significa, em números absolutos, que estas injúrias esportivas, são motivos de preocupação econômica para os clubes ou patrocinadores do atleta.

Ante tal realidade, clubes e seleções de vários países começam a se preocupar com a saúde bucal de seus atletas e passam a inserir nas 
comissões técnicas mais um profissional: o Cirurgião-Dentista, que é tão importante para o bom desempenho do atleta quanto o Médico, o Fisioterapeuta, o Nutricionista e o Massagista.

No Brasil são raros os estudos epidemiológicos sobre traumatismos buco-dentários e condições de saúde bucal de atletas. O mesmo não ocorre nos países desenvolvidos, particularmente nos Estados Unidos da América, onde o próprio governo tem financiado muitas pesquisas sobre este tema, enfatizando a necessidade de prevenir tais injúrias. (BIJELA et al. ${ }^{15}$ )

Segundo CANTO et al. ${ }^{18}$, em 1999, enquanto há um forte enfoque na Odontologia Preventiva quando o assunto é cárie, somente poucos indivíduos parecem preocupados em evitar traumas que podem ocorrer nos dentes e/ou estruturas de suporte devido aos impactos, principalmente nos esportes.

Em relação ao padrão de higiene bucal, as más-condições de higiene e de saúde bucal tem repercussões sistêmicas. A aspiração de secreções purulentas, exsudato e agentes etiológicos patogênicos de produtos sépticos e tóxicos que são resultado de bactérias e células humorais em decomposição juntamente com o ritmo respiratório ofegante do atleta, facilitam a penetração desses elementos na corrente sangüínea e pulmões, resultando em bacteremia e redução da capacidade respiratória por inflamação dos tecidos pulmonares. 
O esforço para se obter um organismo saudável e uma melhora na qualidade de vida está cada vez mais integrado as aspirações da sociedade. Desta forma, a consciência da importância da saúde bucal é um fator de crescente preocupação do ser humano. Torna-se fundamental a conscientização e o emprego de estratégias com as seguintes finalidades: 1) prevenção de traumatismos dentários, 2) prevenção de repercussões sistêmicas conseqüentes de um inadequado padrão de higiene bucal e 3) motivação dos praticantes de atividades esportivas a freqüentarem o consultório odontológico. 
2 REVISÃO DA LITERATURA 


\section{REVISÃO DA LITERATURA}

EPSTEIN ${ }^{29}$, em 1962, afirmou que as lesões causadas por pancadas nos dentes e tecidos de proteção e sustentação, levam a injúrias que podem resultar desde o abalo dentário até a perda do elemento associada a fraturas dos tecidos de sustentação e dilacerações do tecido de proteção, além da freqüente mortificação pulpar.

No ano de 1965, STEVENS ${ }^{80}$, avaliou doze tipos de protetores bucais usados por atletas de futebol americano, através de um questionário que foi distribuído a 592 jogadores de várias equipes, com a finalidade de determinar o melhor protetor bucal a ser usado nos anos seguintes. Nos resultados puderam ser observadas as características dos vários tipos de protetores bucais analisados, independente da marca, material ou tipo de fabricação. Segundo o autor, no comércio internacional, nas lojas de materiais esportivos e de artigos de odontologia pode-se adquirir protetores pré-fabricados, entretanto, os mais adequados seriam aqueles fabricados sob medida, após uma prévia moldagem dos arcos dos indivíduos, haja visto que as vantagens de um protetor feito sob medida referem-se à possibilidade de reproduzir a perfeita anatomia do arco dentário, oferecendo maior estabilidade ao protetor, diminuindo a ocorrência de deslizamentos durante os movimentos bucais, além de permitir que se façam adaptações necessárias de acordo com o tipo de esporte praticado. 
Em 1966, GODDEN ${ }^{37}$ elaborou um estudo e um questionário dirigidos às entidades ligadas a prática de esportes de contato objetivando obter avanços no que concerne a minimização das injúrias orofaciais, buscando uma padronização dos diversos tipos de protetores bucais existentes.

No ano seguinte, HICKEY et al $^{39}$ realizaram estudos em cadáveres do sexo masculino, utilizando dois tipos de protetores bucais (um feito em vinil e outro feito em látex), para suportarem golpes na parte inferior da mandíbula, afim de relacioná-los com a deformação e a pressão intracraniana recebidas pelos mecanismos de produção de impacto dos ataques no futebol americano. Os autores concluíram que os protetores bucais reduziam de forma acentuada as pressões intracranianas e as deformações dos ossos do crânio.

NICHOLAS ${ }^{60}$, em 1969, na Nova Zelândia, publicou sobre a proteção bucal nos esportes de contato, afirmando que os principais objetivos do uso dos protetores bucais são: proteção dos dentes anteriores e lábios, proteção contra golpes diretos, proteção de danos às cúspides e/ou restaurações dos dentes posteriores causados pelo impacto da mandíbula, proteção de tecidos moles (lábios, bochechas e língua), prevenção de estragos na ATM, prevenção de concussão cerebral e outros danos intracranianos mais sérios. 
De acordo com De WET ${ }^{25}$, em 1981, no momento da ocorrência de um traumatismo dentário a maior parte dos pais e alguns CirurgiõesDentistas tem dúvida no que fazer. Por esta razão, a situação ideal é que haja uma equipe de Cirurgiões-Dentistas quando existe a possibilidade de um traumatismo dentário acontecer e, que um Odontólogo pode facilmente pertencer a uma equipe e/ou um número de equipes, atuando como um profissional conselheiro, ajustando protetores bucais e assegurando que 0 traumatismo dentário ou outras enfermidades dentárias sejam tratadas pelos Cirurgiões-Dentistas particulares dos atletas. O autor também deixou claro que os protetores bucais são efetivos na redução dos traumatismos bucofaciais em atletas que praticam esportes de contato, e que estes protetores deveriam ser usados por equipes desde a escola primária até os profissionais.

Em relação ao o mecanismo da ação dos protetores bucais JOSELL; $\mathrm{ABRAMS}^{47}$, em 1982, publicaram que estes dispositivos funcionam como almofada distribuindo as forças durante o golpe, prevenindo a laceração e equimose dos lábios e bochechas durante o impacto, evitando também, que os dentes do arco oposto sofram contatos traumáticos, os quais poderiam fraturar os dentes ou danificar suas estruturas de suporte. Os autores concluíram que quanto mais espesso o protetor, maior é a proteção oferecida pelo mesmo, já que a força transmitida através do material protetor é inversamente proporcional a sua espessura. 
Também em 1982, WIJN et al ${ }^{84}$ declararam que se as características de desenho dos protetores bucais fossem melhoradas, poderiam ser de maior importância quando este desenho estiver associado com a utilização de materiais com qualidades para atenuar os impactos.

Em 1983, QUINN ${ }^{70}$ relatou, após um amplo estudo de ferimentos sofridos por atletas do futebol australiano, que existia uma grande incidência de traumatismos na região orofacial. O autor concluiu que o protetor intraoral é muito recomendado para os jogadores de ataque do futebol australiano, bem como o seu uso no boxe, artes marciais e cricket, além da sua indicação para jogadores submetidos a tratamentos ortodônticos.

A AMERICAN DENTAL ASSOCIATION², em 1984, após analisar várias pesquisas, a respeito dos traumatismos orofaciais relacionados à prática esportiva, recomendou o uso de protetores bucais nos seguintes esportes: acrobacia, basquete, hockey, futebol americano, ginástica olímpica, handebol, artes marciais, jogos com raquetes, rúgbi, skate, ski aquático e de neve, squash, surf, vôlei e pólo aquático. A ADA também recomendou que durante a fabricação do protetor bucal deve-se levar em conta os seguintes critérios: adaptação, retenção e estabilidade do material. Depois de confeccionado, o protetor deve interferir o mínimo na fala e na respiração, ser confortável, resistente, sem odor, sem gosto, ter excelente retenção e ajuste, e suficiente espessura e áreas críticas. 
No mesmo ano, ANDREASEN; ANDREASEN ${ }^{5}$ publicaram que o número de casos de traumatismos em dentes anteriores permanentes tem sido muito freqüente nos consultórios odontológicos, sendo que as lesões mais comuns em traumatismos dentários são as fraturas coronárias de esmalte e dentina, avulsões e fraturas coronárias com exposição pulpar, atingindo principalmente os incisivos centrais superiores. Os autores afirmaram que a ocorrência de traumatismos dentários é duas vezes maior nos indivíduos do sexo masculino, devido a uma maior participação destes em esportes.

Ainda em 1984, DREYER ${ }^{28}$ publicou que o Cirurgião-Dentista especialista em Odontologia Desportiva tem a responsabilidade de fornecer aos treinadores e técnicos, informações sobre o procedimento de emergência em casos de traumatismos orofaciais e, principalmente, conscientizá-los sobre a prevenção destes acidentes através da orientação quanto ao uso de acessórios de segurança ideais para cada esporte.

No mesmo raciocínio, NOVICH; SCHWARTZ ${ }^{62}$, em 1985, revelaram que após realizarem um trabalho de conscientização da prevenção de traumatismos dentários com halterofilistas, concluíram que estes obtiveram um aumento de $20 \%$ em seu rendimento quando começaram a usar os protetores intrabucais, fato este que se deve a sensação de segurança pelo atleta. 
Também em 1985, CHAPMAN ${ }^{21}$, afirmou que a proteção dental e de tecidos adjacentes através do uso de protetores bucais, teve uma grande influência na redução de impacto contra a mandíbula nos jogadores de rugby.

GARON; MERKLE; WRIGHT ${ }^{35}$, em 1986, realizaram um estudo com 754 jogadores de futebol americano com idade de 12 a 18 anos, os quais foram submetidos a uma avaliação médica e odontológica, incluindo o uso ou não de protetores bucais. Os autores observaram que os atletas que usavam protetor foram capazes de reduzir em 50\% o número de injúrias das estruturas dentárias na prática do futebol americano. Os autores também analisaram jogadores de basquete possuidores de protetores intra-orais e concluíram que houve uma diminuição dos ferimentos em até sete vezes, comparados aos não possuidores. Esta redução foi mais evidente no número de dentes fraturados e avulsionados.

Em 1988, SANE; YLIPAAVALNIEMI ${ }^{77}$ afirmam que os traumatismos ocasionados na prática esportiva representam uma parcela importante, de 14 a 39\%, entre as etiologias do traumatismo dentário. Os autores também afirmaram que com o aumento do número de praticantes de esportes de contato e o aumento da competitividade, a tendência é de aumento substancial nas estatísticas envolvendo acidentes traumáticos no esporte. 
Também em 1988, CHELOTTI; VALENTIN ${ }^{22}$ relataram que pacientes portadores de classe II - divisão 1 de Angle (overjet acentuado e sem vedamento labial), possuem proteção insuficiente dos lábios, sendo esta característica um fator predisponente para os traumatismos dentários. Segundo os autores, os pacientes com estas características possuem cinco vezes mais predisposição para traumatismos do que os pacientes que apresentam oclusão normal. Outro ponto importante relatado neste trabalho é a variação dos traumatismos segundo as estações do ano, pois parece existir uma relação entre a época do ano e a freqüência das lesões dentárias. No Brasil, as lesões dentárias têm seu pico nas férias de verão, enquanto nos EUA, a maior ocorrência foi observada no período escolar durante a prática de jogos e esportes de inverno.

MAESTRELLO-DE-MOYA; PRIMOSCH${ }^{57}$, em 1989, examinaram a prevalência e os tipos dos ferimentos orofaciais entre os 1020 jogadores de basquete da High School (ensino médio) da Florida durante uma temporada. Os autores também examinaram a prevalência, os tipos de protetores bucais usados e sua influência na prevenção de traumatismos e ferimentos. Os resultados demonstraram que: 1) a maioria dos traumatismos foi nos tecidos moles; 2) o número de jogadores que não usavam protetores bucais foi 977 , enquanto 43 eram usuários; 3) houve uma incidência de $32 \%$ de ferimentos nos não usuários e de apenas 4\% nos usuários de protetores. 
Também em 1989, MC NUTT ${ }^{58}$ et al. escreveram que os traumatismos dentários poderiam ser evitados se houvesse um esforço conjunto de pais, Odontólogos e treinadores em incentivar os atletas a usarem os protetores bucais durante treinos e jogos. Os autores ainda afirmaram que o primeiro protetor bucal foi usado por Ted "Kid" Lewis (boxeador inglês), em 1913.

De acordo com BIJELLA ${ }^{15}$ et al., em 1990, no Brasil são raros os estudos epidemiológicos sobre traumatismos orofaciais e de prevenção para os mesmos. O que não ocorre em outros países, particularmente nos Estados Unidos, onde o próprio governo tem financiado pesquisas sobre este tema, enfatizando a necessidade de prevenir tais injúrias, principalmente com o uso do protetor bucal ou facial, dependendo da modalidade esportiva praticada.

CHANDRA $^{20}$, também em 1990, mostrou que na Austrália a prevenção e a preparação adequadas para a prática esportiva reduziram consideravelmente as injúrias apresentadas pelos atletas, que eram cerca de $30 \%$ a $50 \%$.

No ano seguinte, ANDREASEN; ANDREASEN ${ }^{6}$, afirmaram que estudos epidemiológicos sobre traumatismos buco-dentários revelam que estes são mais prevalentes na infância e adolescência devido às características das atividades envolvidas durante as etapas da vida, não 
sendo raros entretanto, na fase adulta, principalmente devido ao aumento no número de praticantes de esportes e acidentes de trânsito. Estas informações também foram afirmadas por JOHNSON ${ }^{44}$ e HIDASI; TARJAN; CSOROGI $^{40}$.

Segundo JOHNSEN; WINTERS ${ }^{43}$, também em 1991, com o aumento da prática esportiva entre crianças e adolescentes, a Odontologia Esportiva tende a se tornar um campo de atuação em expansão do odontopediatra. Os autores ainda afirmaram que a falta de interesse ou preocupação com a Odontologia Esportiva faz com que o profissional perca a oportunidade de ampliar sua área de atuação, principalmente em clubes que possuem grandes patrocinadores.

PAVARINI; GARIB ${ }^{66}$, em 1993, escreveram que a prevalência de traumatismos bucais no Brasil tem aumentado significativamente. Embora não existam dados nacionais sobre o assunto, o Cirurgião-Dentista não pode negar que, pela freqüência de pacientes com traumatismos bucais de tecidos moles ou duros que procuram assistência odontológica, a prevalência destas injúrias em nosso meio também seja grande. Os autores acrescentam, que apesar disto, até o momento não existe qualquer regulamentação sobre o uso de protetores bucais, nem mesmo orientações sobre a prevenção de traumatismos buco-dentários. 
Também em 1993, LANCASTER; RANALLI ${ }^{52}$ realizaram uma pesquisa com a finalidade de avaliar as atitudes dos juízes de futebol americano diante do regulamento da Associação Nacional de Atletas Universitários (NCAA - National Collegiate Athletic Association), sobre o uso dos protetores bucais pelos jogadores. As atitudes dos juízes foram comparadas com resultados obtidos previamente em outro estudo feito em 1990. Um questionário com doze itens, idêntico ao de 1990, foi enviado para sessenta e dois árbitros. Seis semanas depois, os questionários respondidos foram devolvidos. As respostas foram computadas e análises estatísticas foram utilizadas para compará-las com as respostas do estudo de 1990. Noventa e cinco por cento dos juízes responderam ao questionário. Vinte e sete por cento responderam que todos os jogadores se submetiam ao regulamento, 74\% acreditavam que o regulamento ajudava na concordância do jogador ao uso do protetor bucal e $20 \%$ responderam que a regra resultou em maior freqüência do uso do protetor bucal. Vinte e dois por cento responderam que ignorariam uma violação no uso do protetor bucal e nenhum um time ou um jogador por essa razão no campeonato de 1991. Comparativamente ao estudo de 1990 algumas diferenças foram detectadas: (1) os estudos discordavam sobre jogadores de quais posições usavam mais ou menos o protetor bucal; (2) cinqüenta e dois por cento dos juízes entrevistados em 1990 achavam que o regulamento resultava em uma maior freqüência no uso do protetor bucal pelo jogador, enquanto no estudo atual apenas 20\% eram da mesma opinião; (3) zero por cento dos juízes entrevistados em 1990 ignorariam a violação do regulamento em questão 
contra 22\% dos juízes do estudo atual. Os autores concluíram que: (a) os juízes não gostavam de penalizar jogadores pela não uso do protetor bucal e (b) os juízes achavam que os técnicos deveriam ser responsáveis por fazerem os jogadores usarem o protetor bucal.

FLANDERS ${ }^{32}$, ainda em 1993, revisou literatura especializada sobre protetores bucais e lesões na prática de esportes com a finalidade de fazer um alerta à classe odontológica sobre a prevenção de traumatismos orofaciais. O autor concluiu que o dentista tem um importante papel na informação de atletas e pacientes sobre o uso de protetores bucais, devendo providenciar o tipo apropriado de protetor para cada indivíduo. Para isso, o Cirurgião-Dentista deveria questionar todos os pacientes sobre as atividades esportivas praticadas e de posse dessas informações determinar o risco de lesões.

De acordo com TANAKA et al. ${ }^{81}$, em 1994, os traumatismos maxilofaciais em praticantes de esportes com idades entre 10 e 30 anos, no período de 1977 a 1989, foram 15\% do total de traumatismos que deram entrada no Hospital da Universidade de Tóquio - Japão.

Também em 1994, DEYOUNG; ROBINSON; GODWIN ${ }^{26}$ realizaram um estudo com a finalidade de comparar o conforto e a adaptação de protetores bucais pré-fabricados ou termoplásticos e protetores bucais feitos sob medida em atletas colegiais. Vinte atletas do sexo masculino e vinte do 
sexo feminino foram selecionadas para participar desse estudo. As moldagens dos quarenta colegiais foram feitas por uma cirurgiã-dentista. Após responderem um questionário, dez meninos e dez meninas usaram protetores bucais pré-fabricados primeiro, seguido pelo uso do protetor bucal feito sob encomenda. A outra metade usou primeiro o protetor feito sob medida e depois usou o protetor bucal pré-fabricado. Os atletas usaram cada protetor por duas semanas durante treinos e jogos. No fim desse período um segundo questionário foi aplicado aos quarenta atletas. Esse questionário perguntava sobre o conforto e a adaptação do protetor bucal. Duas semanas após o segundo questionário ser aplicado, foi aplicado um terceiro questionário contendo as mesmas questões do anterior. Durante o estudo $44 \%$ dos meninos e $30 \%$ das meninas sofreram traumatismos na cabeça e no pescoço enquanto usavam protetores bucais termoplásticos. Trinta e um por cento dos meninos e $40 \%$ das meninas sofreram esses traumatismos enquanto usavam protetores bucais feitos sob medida. Nenhum traumatismo intrabucal foi detectado. Dois participantes disseram que suas mucosas bucais ficaram irritadas com o uso do protetor bucal feito sob medida. Quatorze participantes apresentaram irritação gengival nas áreas da tuberosidade maxilar com o uso do protetor bucal pré-fabricado. Quinze participantes relataram perda do protetor bucal pré-fabricado. Não houve nenhum relato quanto à perda de adaptação do protetor bucal feito sob medida. Quatro atletas tiveram dificuldade de fala usando o protetor bucal feito sob medida, enquanto treze tiveram a mesma dificuldade com o protetor bucal pré-fabricado. Quatorze atletas reclamaram da dificuldade de 
respiração com o protetor bucal feito sob medida. Vinte e oito fizeram essa mesma reclamação com o uso do protetor bucal pré-fabricado. Oito meninas tiveram problemas tentando adaptar o protetor bucal pré-fabricado. Apenas um menino teve a mesma dificuldade. Os autores concluíram que: (1) a maioria dos participantes $(86,1 \%)$ prefere protetor bucal feito sob medida. (2) Participantes do sexo feminino toleram menos os protetores bucais préfabricados. (3) Quando o custo está em questão, os atletas do sexo masculino preferem os protetores bucais pré-fabricados, que são mais baratos e mais fáceis de serem obtidos. (4) Os dois tipos de protetores testados oferecem adequada proteção contra traumatismos orofaciais.

Dando continuidade ao estudo realizado em 1993, RANALLI; LANCASTER $^{72}$ avaliaram, em 1995, a atitude de técnicos de futebol americano frente ao regulamento da Associação Nacional dos Atletas Universitários (NCAA) e compararam as respostas dos técnicos com as dos juízes que foram obtidas no estudo anterior. Um questionário com quinze itens foi mandado a cento e seis técnicos de futebol americano. Quatro semanas depois os questionários foram devolvidos e as respostas computadas. Foi utilizado um sistema de análise estatística para a comparação. Noventa e dois por cento dos questionários foram respondidos. Oitenta e sete por cento dos técnicos disseram ter um Dentista responsável pelo time. Trinta e três por cento relataram preferir protetores bucais feitos sob encomenda, 33 \% não tinham preferência entre protetores bucais feitos sob encomenda e termoplásticos e $27 \%$ preferiam os termoplásticos. 
Cinqüenta e seis por cento dos técnicos responderam que quem determina o tipo de protetor bucal a ser usado é o treinador do time, apenas cinco por cento disseram ser o Dentista. Cinqüenta e três por cento dos técnicos afirmaram que todos os jogadores de futebol americano usavam protetor bucal. Quarenta e cinco por cento disseram que a maioria dos jogadores faz uso do aparelho. Setenta e quatro por cento dos técnicos advertiriam o jogador que não usasse protetor bucal. Mais técnicos do que juízes de futebol americano (34\%) achavam que todos os jogadores usavam protetor bucal. Menos juízes (35\%) do que técnicos de futebol americano (54\%) afirmaram que o regulamento da NCAA aumentou a freqüência do uso do protetor bucal pelos jogadores. Mais juízes (38\%) do que técnicos (2\%) achavam as regras do regulamento inapropriadas.

Segundo $\mathrm{KONIS}^{49}, \mathrm{DAVIS}^{24}$, em 1995, a Odontologia Esportiva é o tratamento e, principalmente, a prevenção de traumatismos orofaciais, doenças orais relacionadas e suas manifestações, envolvendo desde o primeiro atendimento no local do acidente, assim como o tratamento dentário e suas conseqüências. Estes autores afirmaram que nesta especialidade existe a necessidade de diagnóstico diferencial de ferimentos não dentários relacionados e normas gerais de encaminhamento para o médico apropriado, ou seja, se um paciente tiver um dente quebrado ou avulsionado, o dentista deve verificar o estado sistêmico total do paciente, a possibilidade de haver ferimento na cabeça ou contusão e encaminhar ao médico apropriado antes do tratamento dentário. 
FLANDERS $^{33}$, no mesmo ano, relatou que o aumento da incidência dos traumatismos faciais seria o maior problema de saúde dos Estados Unidos. Muitos desses traumatismos eram buco-faciais resultantes de atividades esportivas. Segundo o autor a classe odontológica poderia prevenir muitos desses problemas, trabalhando junto com técnicos, pais e professores, ajudando a desenvolver programas efetivos em escolas e faculdades. O autor concluiu que promover o uso de protetores bucais em escolas estaduais e educar sobre os benefícios desse uso são medidas eficazes para reduzir significativamente o número de traumatismos bucais e faciais.

Também em 1995, DAVIS ${ }^{24}$ publicou que existem vários tipos de protetores bucais no mercado; o tipo mais indicado é o que é feito especialmente para o paciente. Para isso o Dentista deve saber de alguns dados sobre o atleta, antes da confecção do protetor, como por exemplo para qual esporte está sendo projetado, a idade do atleta, e se a possibilidade de fornecer espaço para dentição mista irá afetar o protetor, se o "design" será apropriado para o respectivo nível de competição, o histórico do paciente em relação a ferimentos dentários ou contusões, se há necessidade de proteção adicional em alguma área específica, se ele está sofrendo algum tratamento, se tem cavidades ou falta de dentes, etc. 
Segundo RANALLI ${ }^{71}$, em 1995, escreveu um artigo sobre os tipos de protetores bucais considerados pela American Society for Testing and Materials (ASTM), o tipo I é o protetor bucal de estoque, que oferece proteção limitada por não adaptar-se bem, interferindo na fala e na respiração do atleta. O tipo II é o protetor termoplástico, sendo melhor que o de estoque, porém não possui uma retenção ideal. O tipo III é o protetor feito sob encomenda, que oferece melhor adaptação e proteção superior na prevenção de traumatismos. Este protetor requer visitas ao consultório odontológico, portanto seu custo é maior. Entretanto, o autor enfatizou que esse custo é inferior ao do tratamento de um traumatismo buco-facial.

Continuando no ano de 1995, KALINA ${ }^{48}$ analisou o papel do dentista na promoção de uso do protetor bucal. A autora relatou que tanto a American Dental Associantion (ADA) como a Academy for Sports Dentistry (ASD) encorajam os dentistas a participarem ativamente de programas de promoção do protetor bucal, auxiliando na prevenção de 200.000 traumatismos buco-faciais que ocorrem anualmente. Segundo a autora, com educação, dedicação e trabalho em grupo os profissionais de odontologia podem vencer a luta contra os traumatismos que ocorrem com durante a prática esportiva. A autora alertou também para a importância da participação dos pais, treinadores, professores e crianças, assim como de toda a sociedade para fazer da prevenção um assunto não para a página de esportes dos jornais, mas para a primeira página. 
No mesmo ano, GLASSMAN ${ }^{36}$ publicou que por causa do envolvimento de crianças cada vez mais novas na prática de esportes, a incidência de traumatismos dentários e orofaciais está em ascensão nos Estados Unidos. A autora enfocou os gastos com traumatismos dentários e as medidas que podem ser tomadas para reduzir significativamente o risco dessas injúrias durante a prática esportiva. GLASSMAN ${ }^{36}$ afirmou que Odontologia Esportiva é mais do que necessária e que o protetor bucal é a primeira linha de defesa contra os traumatismos orofaciais.

Ainda em 1995, JOLLY; MESSER; MANTON ${ }^{46}$ afirmaram que o uso de protetores bucais vai além da garantia de saúde para os atletas. Visto que, estes dispositivos garantem também uma economia significativa para os clubes em relação aos tratamentos odontológicos. Os autores também afirmaram que quando os protetores bucais não são usados, fraturas e avulsões dentárias são no mínimo duas vezes mais freqüentes do que quando estes são utilizados.

ANDRADE $^{4}$, em 1996, publicou sobre a convocação de acadêmicos de odontologia para fazer acompanhamento das seleções de futebol. O autor escreveu que considerando que a maioria dos times desconhece os benefícios que um Cirurgião-Dentista pode oferecer aos atletas, apenas 10 dos 42 grandes clubes nacionais mantêm consultório dentário em suas sedes. Como conseqüência, $67 \%$ dos 283 jogadores que passaram pela Granja Comary, centro de treinamentos da CBF em Teresópolis - RJ, no 
período de janeiro de 1992 a janeiro de 1996, apresentavam problemas bucais. O autor comentou que a nata do esporte mais popular do Brasil falha no que se refere à preservação dos elementos dentais.

Também e 1996, PRIETO; DAVIDOWICZ; MOURA ${ }^{67}$ realizaram uma revisão da literatura e afirmam que realmente a proteção das estruturas dentárias e orofaciais nos esportes de contato como em outras atividades na infância e adolescência é alvo de inúmeros estudos os quais buscam, cada vez mais, o aprimoramento de técnicas que visam obter os menores índices possíveis de injúrias às estruturas mencionadas. Neste particular a utilização de protetores intrabucais e barras faciais, confeccionadas sob diferentes técnicas, decrescem de forma significativa os ferimentos orofaciais e em particular os traumas dentários.

No ano seguinte, KUMAMOTO et al. ${ }^{50}$ publicaram um estudo sobre a incidência de lesões orofaciais no basquete, que atinge até $30 \%$ do total de injúrias, sendo maior em atletas homens (10\%) do que em mulheres (7,5\%). Dos 33 atletas estudados, a porcentagem dos pacientes que relataram avulsão dentária em partidas de basquete apresentou-se da seguinte forma: 21,2\% tiveram vários dentes avulsionados, sendo $81,1 \%$ das injúrias em incisivos centrais superiores, $9,7 \%$ em incisivos laterais superiores e o restante incidindo sobre os outros elementos dentais. O autor relata que acidentes como as avulsões dentárias acontecem freqüentemente no basquete na manobra de "enterrar" a bola na cesta, quando os dentes ficam 
presos na rede, causando injúrias severas, que poderiam ser evitadas com o uso de protetores bucais.

Também em 1997, HAMILTON et al. ${ }^{38}$ realizaram uma pesquisa na Inglaterra, através de questionários enviados a professores de Educação Física, enfermeiras escolares, secretárias, atendentes de escolas de natação e 220 pais de crianças. Foi avaliado o conhecimento dessas pessoas no manuseio de dentes incisivos permanentes avulsionados. Os autores constataram que tanto os grupos de profissionais investigados como os pais não tinham de modo geral, conhecimentos adequados de como agir em situações de emergência envolvendo avulsões dentárias.

Ainda em 1997, DIAB; MOURINO ${ }^{27}$ avaliaram a postura dos pais frente ao uso do protetor bucal pelos seus filhos, visando promover educação nessa área. Um questionário com onze perguntas foi enviado a 1800 pais de alunos da quarta série ao primeiro ano colegial de uma escola pública da Virginia (EUA). Os pais foram instruídos a responderem aos questionários e devolvê-los em duas semanas. Vinte por cento dos questionários (359) retornaram. A razão mais freqüente de uma criança não usar o protetor bucal, de acordo com os pais foi: "Não pensei no assunto". Foram relatados 206 casos de traumatismos, 12\% com o uso do protetor bucal e $88 \%$ na ausência do protetor bucal. Os traumas mais freqüentemente relatados foram: corte nos lábios (40\%), fratura dentária (12\%), perda dos dentes (10\%) e fratura de mandíbula (1\%). Os tecidos 
sofreram traumas em $71 \%$ dos casos. Os pais de crianças que já sofreram injúrias dentárias eram mais a favor do uso do protetor bucal. Conclusões dos autores: (1) os pais acham que a obrigação do uso do protetor bucal pelos atletas é responsabilidade deles mesmos e dos técnicos; (2) os pais são favor da obrigatoriedade do uso do protetor bucal no regulamento de esportes como: futebol americano, hóquei, boxe e karatê; (3) poucos pais acham necessário o uso de protetor bucal na prática de esportes como: basquete, baseball e futebol; (4) poucos pais são a favor do uso do protetor bucal a menos que sua criança já tenha sofrido traumatismos dentários, o esporte seja de contato ou seja obrigatório o uso do aparelho no regulamento daquele esporte e (5) os pais acham que os protetores bucais devem ser mais exigidos de seus filhos do que de suas filhas que praticam esportes.

Posteriormente, em 1998, ARAÚJO; CORMACK ${ }^{9}$ publicaram dados obtidos nos exames odontológicos realizados entre 312 jogadores das Seleções Brasileiras de Futebol com idade variando entre 14 a 34 anos, sendo 283 do sexo masculino e 29 do sexo feminino, na Granja Comary, centro de treinamentos da CBF, em Teresópolis - RJ, durante um período de 4 anos (janeiro de 1992 a janeiro de 1996). O trabalho foi compreendido em três partes distintas: diagnóstico de saúde oral, atendimento de emergência e programa preventivo. Foram encontrados 33\% dos atletas sem problemas de saúde bucal, $47 \%$ com pequenos problemas e 20 com grandes problemas. Apenas $51 \%$ dos atletas possuíam todos os dentes, e 
46\% apresentaram perda de 1 a 5 elementos. Quanto aos hábitos viciosos $38 \%$ dos atletas não apresentaram nenhum tipo, enquanto que 54\% dos atletas roem unha e a pele dos dedos, enquanto os $8 \%$ restantes apresentaram bruxismo, respiração bucal, deglutição atípica ou hábito de chupar o dedo. Em relação as maloclusões $29 \%$ dos atletas examinados eram portadores de maloclusão Classe II de Angle e 5\% Classe III, sendo que nesses dois grupos foram diagnosticados $47 \%$ com problemas na ATM, constando crepitações e estalos. Os autores chegaram à conclusão que o alto percentual (67\%) de jogadores das Seleções Brasileiras de futebol com grandes e pequenos problemas de saúde oral demonstrou a falta de interesse dos clubes e dirigentes pela manutenção da saúde de seus atletas, provavelmente devido à desinformação quanto a relação da saúde oral com a saúde geral.

Também em 1998, PRIETO; DAVIDOWICZ; MOURA ${ }^{68}$ realizaram um estudo visando a elaboração de um questionário a ser enviado a diversas entidades relacionadas à prática de esportes de contato, quanto ao uso de protetores intra-orais, no intuito de se comparar a utilização e a conscientização em diversos países e no Brasil. Segundo eles, a inexistência de um posicionamento da atual situação desta problemática no Brasil indica a necessidade de um trabalho de campo inicial, visando o estabelecimento no que se refere à freqüência do uso, situações e tipos de aparelhos no mercado interno para posterior elaboração de trabalhos, buscando assim uma maior conscientização da população e conseqüentes 
indicações de aparelhos ideais, enquadrando-os à situação sócio-econômica do país. Os autores concluíram que só após a obtenção dos questionários respondidos, existiria a possibilidade de haver uma coadjuvância de métodos preventivos aos traumatismos dentários que ocupam pequena porcentagem nas pesquisas destas patologias, onde o maior montante deste estudo se concretiza no tratamento dessas injúrias, uma vez instalados.

Dando continuidade ao estudo anterior, PRIETO; DAVIDOWICZ; MOURA $^{69}$, no mesmo ano, elaboraram e aplicaram um questionário com dez perguntas direcionadas ao uso do protetor bucal. Foram enviados 80 questionários para cinco entidades esportivas diferentes: basquete - Clube Círculo Militar, boxe - Universidade de São Paulo, Jiu-Jitsu - Academia Fábio Gurgel, rugby - Faculdade Mackenzie, e o vôlei - Colégio Giordano Bruno. Através dos resultados obtidos os autores puderam concluir que: (1) o boxe obteve um maior percentual de utilização do protetor bucal, ou seja $100 \%$, seguido pelo rugby com $75 \%$, o basquete com $63,3 \%$, o jiu-jitsu $58 \%$ e o vôlei 0\%; (2) quanto ao tipo de protetor bucal utilizado, os de estoque convencional obtiveram $44,7 \%$ de utilização, o de estoque tipo termoajustáveis obtiveram $34,2 \%$, e os confeccionados individualmente em consultório odontológico obtiveram apenas 21,1\%. Do total de questionários, apenas $16 \%$ foram respondidos de forma completa. Os autores também publicaram as respostas dos questionários nas entidades esportivas participantes. 
Ainda em 1998, FERREIRA ${ }^{31}$ publicou que a Odontologia Desportiva é um ramo da Odontologia, ainda pouco explorado, especializado no tratamento e na prevenção dos traumas e doenças orais oriundos da prática esportiva. O autor diz que o Cirurgião-Dentista deve detectar todos os problemas do atleta, como a respiração bucal e o mau posicionamento das arcadas, além de saber administrar corretamente medicamentos livres de substâncias que possam acusar doping positivo, presentes em muitos analgésicos e anestésicos. Deve ainda, realizar o pronto atendimento nos locais das práticas desportivas, fazendo diagnósticos diferenciais e determinando o futuro tratamento ou prognóstico dos traumas. O autor também reafirmou a necessidade do uso de protetores bucais pelos atletas, alertando que os traumatismos dentários são os mais comuns que ocorrem na face durante as competições esportivas e que o uso dessa proteção influencia também os jogadores psicologicamente, trazendo-Ihes segurança e impulsividade.

ARAÚJO ${ }^{11}$, em 1999, afirmou que devido às múltiplas causas dos traumatismos bucais, a prevenção envolve muitas áreas de conhecimento como a engenharia de controle, a educação, promulgação e execução de legislação, citando como exemplo o caso dos automóveis onde a engenharia de controle determina a presença de air bag, cintos de segurança e painéis de proteção que se constituem em dispositivos para prevenir ou minimizar os traumatismos. Segundo o autor, compete aos Cirurgiões-Dentistas educar a população quanto aos aspectos preventivos, baseados na experiência e 
capacidade de observação do paciente, informando-o sobre suas condições clínicas predisponentes aos traumatismos, além da responsabilidade de tornar pública e executar a legislação designada a prevenir ou minimizar injúrias bucais. O autor citou ainda que as medidas preventivas a serem adotadas pelos Cirurgiões-Dentistas são as seguintes: uso de protetores bucais e capacetes, tratamento de maloclusões classe II - 1 de Angle, encaminhamento médico aos pacientes respiradores bucais, planejamento adequado de restaurações em dentes fragilizados, e orientação aos pais quanto a sua situação dentária e risco de fraturas.

Também em 1999, CANTO et $\mathrm{al}^{18}$. revisaram a literatura sobre protetores bucais e fizeram algumas considerações: (1) é importante que os jovens envolvidos com exercícios físicos e esportes de contato disponham de proteção mais adequada; (2) os protetores bucais conferem um alto grau de proteção aos dentes e estruturas de suporte, por isso devem fazer parte dos equipamentos de proteção utilizados pelos atletas; (3) as associações esportivas deveriam possuir Cirurgiões-Dentistas em suas equipes para promover a saúde bucal dos atletas; implantar um programa contra traumatismos dentários e tratar os casos de emergência; (4) é necessário um esforço conjunto de pais, Cirurgiões-Dentistas e treinadores no sentido de convencer os atletas sobre os riscos da participação em atividades esportivas sem proteção e dessa forma incentivar e exigir o uso de todos os dispositivos disponíveis com essa finalidade e (5) os Cirurgiões-Dentistas 
por sua vez devem possuir conhecimento suficiente para orientar os atletas sobre o tipo de proteção mais eficaz e adequado para cada esporte.

CRITCHLEY et al. ${ }^{23}$, neste mesmo ano, realizaram um estudo em três campeonatos de Karate Shotokan em que o uso dos protetores bucais eram proibido, nos anos de 1996, 1997 e 1998. O resultado encontrado foi de 160 traumatismos, dentre 1770 atletas com idade média de 22 anos. Para os autores, a gravidade e a quantidade das injúrias estão relacionadas com o mínimo de contato desse esporte e, ainda, a gravidade dos traumatismos depende da etiologia, podendo ser prevenidos quando realizados programas específicos de prevenção.

Ainda em 1999, MAESTRELLO; MOURINO; FARRINGTON ${ }^{56}$ analisaram a atitude de Cirurgiões-Dentistas (clínicos gerais, ortodontistas e odontopediatras) frente ao uso do protetor bucal. Um questionário com trinta perguntas foi enviado a 2500 dentistas do Estado da Virgínia (EUA). Quarenta por cento desses questionários retornaram. Os resultados foram: 97\% dos ortodontistas, $84 \%$ dos odontopediatras e $67 \%$ dos clínicos gerais recomendavam o uso do protetor bucal para seus pacientes durante a prática de esportes. As duas razões dadas pelos cirurgiões-dentistas para não recomendarem o protetor bucal foram: (1) o paciente pode obter um protetor bucal de estoque mais barato do que o fabricado no consultório e (2) não ter recebido treinamento formal sobre confecção e uso do protetor bucal. Clínicos gerais (59\%) e odontopediatras (56\%) recomendavam mais o 
protetor bucal feito sob encomenda, enquanto $77 \%$ dos ortodontistas recomendavam o protetor bucal de estoque. Os autores concluíram que: a maioria dos dentistas concorda que a prática esportiva requer o uso do protetor bucal.

No ano de 2000, FERRARI; SIMI Jr.; MEDEIROS ${ }^{30}$, realizaram uma pesquisa com o propósito de verificar a ocorrência de traumatismos dentários em praticantes de diferentes esportes, bem como verificar se os mesmos fazem uso de protetor bucal durante as atividades esportivas e tem ciência da indicação do uso do protetor. Foram realizadas entrevistas com esportistas profissionais e semi-profissionais, praticantes de esportes de contato, questionando a ocorrência de traumatismos dentais durante a prática do respectivo esporte, bem como se o atleta usava protetor bucal e se sabia da sua indicação. Os autores puderam concluir que: (1) Alguns grupos de esportistas estudados possuem maior informação sobre prevenção dos acidentes traumáticos envolvendo a dentição, porém isso nem sempre se traduz em maior índice de uso do protetor bucal. (2) No grupo com maior índice de uso do protetor bucal, ocorreram os menores índices de traumatismo dentário. (3) Precisa-se de campanhas por parte dos Cirurgiões-Dentistas e treinadores para conscientização sobre a prevenção do traumatismo dental durante a prática esportiva.

Segundo OLIVEIRA ${ }^{63}$, neste mesmo ano, a Odontologia Desportiva é um novo campo para os profissionais, ainda pouco explorado. O autor 
identificou esta necessidade e começou um trabalho de divulgação e pesquisa em 1998, que culminou com a criação do Departamento de Odontologia Desportiva, cuja finalidade é coordenar atividades voltadas para esta área. Ele ainda informou que a Odontologia Desportiva tem cinco objetivos principais: 1) estabelecer a saúde da boca, 2) educação nas escolas e comunidades, 3) tratamento de fatores predisponentes, 4) legislação específica para uso de equipamentos durante a prática esportiva e 5)busca de espaço para Cirurgiões-Dentistas nas equipes esportivas.

Também em 2000, LASKIN ${ }^{53}$ alertou para a necessidade de focalizar a prevenção de traumatismos buco-faciais assim como é feito para o tratamento dos mesmos, relatando que nos Estados Unidos a cada ano mais de 250.000 pessoas, a maioria crianças, sofrem traumatismos buco-faciais decorrentes de atividades esportivas e estimou que mais de 100.000 traumatismos poderiam ser prevenidos com o uso de apropriados de proteção da cabeça e da face. O autor analisou como é imprescindível o uso de protetores bucais na prática de esportes como: futebol americano, boxe, beisebol, hóquei, ciclismo, e luta romana. Além do aconselhamento dos pacientes sobre prevenção é fundamental o envolvimento das escolas e da comunidade. Ele ainda destacou que, os Cirurgiões-Dentistas devem cuidar de sua saúde e da saúde dos seus familiares, pois não há melhor meio de educar do que pelo exemplo. 
No mesmo ano, FUTAKI; MOTTA ${ }^{34}$, realizaram um trabalho junto a Faculdade de Educação Física da UNISA com o objetivo de avaliar o conhecimento dos alunos a respeito do protetor bucal e implantar um programa educacional para os mesmos, visando a integração da Odontologia e da Educação Física. Eles idealizaram um questionário para ser distribuído a 680 alunos de Educação Física. Os alunos foram questionados sobre os tipos de injúrias buco-faciais sofridas durante as atividades esportivas, conhecimento e uso dos protetores bucais, tipos utilizados e origem da indicação, entre outros itens. Com base nas respostas, os autores elaboraram uma palestra direcionada especificamente àquela população. Esta foi apresentada à direção da Educação Física e sua aprovação possibilitou a realização de oito palestras para 419 alunos. Terminada a palestra, uma mesa clínica composta de diferentes tipos de protetores bucais foi exibida. Resultados: os tipos de lesões relatados foram de $37,18 \%$ corte nos lábios, 22,20\% ferimentos na língua, 15,64\% injúrias na face, 14,28\% lacerações na bochecha e 10,65\% fraturas dentárias. Verificou-se que $44,15 \%$ não conheciam os protetores bucais. Dos 419 alunos, 5,48\% utilizavam protetor bucal pré-fabricado. Observou-se que $34,79 \%$ foram indicados por técnicos, $21,74 \%$ por dentistas, 4,35\% por professores, 4,35\% por iniciativa própria e 34,79\% por outros. Os autores concluíram que poucos alunos $(5,48 \%)$ utilizavam os protetores bucais e que os alunos de Educação Física deveriam receber mais informações sobre protetores bucais para que possam usá-los e futuramente indicá-los a seus comandados. 
Continuando no ano de 2000, HOLMES ${ }^{41}$, escreveu um artigo de revisão de literatura sobre proteção bucal nos esportes na Escócia. O autor mostrou que embora o uso dos protetores bucais fosse comum por jogadores de alguns esportes como rúgbi e hóquei, atletas de outros esportes não estavam atentos para a necessidade do uso de protetores bucais. Segundo HOLMES ${ }^{41}$, os protetores bucais feitos sobre encomenda ofereceriam melhor proteção que os termoplásticos, mas muitas pessoas não usariam porque eles seriam caros e requeriam visitas ao Dentista. $O$ autor ainda relatou que a estratégia de saúde bucal da Escócia publicada em 1995, recomendava que os Dentistas promovessem o uso do protetor bucal para a redução do risco de injúrias. Mas, haveria uso compulsório do protetor bucal em alguns esportes como rúgbi, boxe, hóquei e ciclismo. Todavia, uso de protetores bucais na prática das artes marciais seria compulsória internacionalmente, mas na Escócia essa regra não seria reforçada pela classe. O autor concluiu que jogadores de esporte de contato têm maiores riscos de sofrerem lesões dento-alveolares e as organizações controladoras desses esportes recomendam que jogadores de todas as categorias usem protetores bucais, mas não o fazem obrigatório.

Ainda em 2000, RODRIGUES; RODRIGUES ${ }^{74}$ publicaram que devido ao fato do crescente número de mergulhadores submarinos, é muito importante para o Cirurgião-Dentista conhecer um pouco mais sobre as patologias hiperbáricas relacionadas ao dente, com a finalidade de evitar o 
barotrauma, já que a cada 10 metros que afundamos a pressão aumenta em uma atmosfera.

No ano seguinte, JALLEH et al. ${ }^{42}$ realizaram uma pesquisa com o objetivo de avaliar um efeito de uma campanha de promoção do uso de protetor bucal entre jogadores de rúgbi e basquete da Austrália. Observouse que o uso do protetor bucal pré e pós-campanha, tanto durante as competições como durante os treinos. Entre os jogadores de rúgbi o uso do protetor cresceu de $77 \%$ para $84 \%$ nas competições depois da campanha e de $29 \%$ para $40 \%$ nos treinos. Já entre os jogadores de basquete o crescimento foi de $23 \%$ para $43 \%$ nas competições e de $11 \%$ para $36 \%$ nos treinos. Os autores concluíram que a campanha teve um efeito significativo e substancial no comportamento dos atletas.

Também em 2001, BOMFIM; COIMBRA; MOLITERNO ${ }^{16}$, revisaram a literatura sobre o potencial erosivo dos repositores hidroeletrolíticos sobre o esmalte dentário. Segundo os autores, estas bebidas foram lançadas no mercado nacional com a proposta inicial de funcionarem como um repositor de líquidos e sais minerais para os praticantes de esportes. Entretanto, em razão do seu sabor agradável e da sensação de "saciar a sede", estas bebidas têm se tornado muito populares, sendo consumidas indiscriminadamente por crianças e adultos. Os autores puderam concluir que: 1) os repositores hidroeletrolíticos apresentam características que podem causar erosão dentária. 2) Devido às pessoas apresentarem uma 
dieta com outros fatores de risco para a erosão dentária, não foi possível determinar que os repositores hidroeletrolíticos sejam tão ou mais erosivos que as demais soluções. 3) Os profissionais devem estar atentos à história médica alimentar de seus pacientes. 4) Para as pessoas que relatam um alto consumo destas bebidas foi aconselhado reduzir o intervalo entre as visitas ao Cirurgião-Dentista, para que este identifique precocemente as lesões iniciais no esmalte.

No mesmo ano, a $\mathrm{APCD}^{8}$ publicou em seu jornal que o CirurgiãoDentista, não familiarizado com os esportes, quando presta atendimento a um atleta, faltam-Ihe alguns conhecimentos específicos. Segundo a APCD já houve caso de um atleta brasileiro não poder competir em uma Olimpíada por causa da Odontologia. Ao fazer um tratamento dentário, e por desconhecimento do Odontólogo, foi ministrado um medicamento que não se descompôs antes de o exame antidoping ser realizado fora do país. Como não havia nada que comprovasse que ele tinha feito um simples tratamento de canal, foi desclassificado. Também foi relatado que o Cirurgião-Dentista que atua na Odontologia Desportiva tem que necessariamente conhecer esportes, a dieta do atleta, os remédios não doping e principalmente o calendário esportivo. Pois para o atleta é completamente inviável fazer um tratamento a partir do mês de setembro. É quando a maioria dos esportes entra na reta final. $E$ isso gera problemas de dor, incômodo e estética que podem influir em sua concentração para competir. 
A $A P C D^{7}$, em 2002, publicou em seu jornal que uma infecção na boca pode provocar muito mais do que dor na vida do atleta. Ela pode ser responsável por problemas que acabem com sua carreira, como a falta de fôlego e distensões. Por isso, a Odontologia Desportiva no Brasil está no estágio de conscientização de clubes e federações esportivas de que o Cirurgião-Dentista é tão importante para o bom desempenho do atleta quanto o Médico, o Fisioterapeuta e o Nutricionista.

Segundo RIBEIRO; GUEDES; SOUZA ${ }^{73}$, em 2002, o esportista deve ser orientado quanto à necessidade e importância da realização de um acompanhamento odontológico periódico por um profissional qualificado. Além disso, o atleta deve ser encorajado quanto ao uso de protetores bucais. Os autores também relataram a necessidade de uma maior conscientização e divulgação no Brasil, sobretudo entre atletas profissionais, das vantagens do uso de protetores bucais na prática esportiva, minimizando e até mesmo prevenindo a ocorrência de injúrias aos tecidos moles bucais e peribucais.

Também em 2002, ARAÚJO; CORMACK ${ }^{10}$ comentaram que os problemas de saúde bucal encontrados nos os atletas das seleções brasileiras de futebol, no período de 1992 a 1996, demonstram a falta de interesse dos grandes clubes do futebol brasileiro e de seus dirigentes pela manutenção da saúde de seus atletas, provavelmente pela desinformação quanto a relação da saúde oral com a saúde geral. Segundo os autores essa 
impressão é reforçada pelo fato de que apenas 10 clubes, dos 42 clubes que serviram jogadores para as seleções, tinham consultórios odontológicos em suas sedes, apresentando uma correlação positiva entre os atletas que tinham grandes problemas dentários que eram oriundos de clubes que não tinham consultórios. Os autores acharam surpreendente o fato de que praticamente nenhum dos clubes realiza um exame de saúde bucal nos seus atletas no início da temporada, do mesmo modo como fazem, rotineiramente, os exames de sangue, de urina, de fezes, etc.

No mesmo ano, VELASCO; MUNHOZ ${ }^{83}$. realizaram uma revisão de literatura, sobre proteção bucal na prevenção de traumatismos dentários, e constataram que: (1) o uso de protetores bucais na prevenção de traumatismos dentários é extremamente importante em atletas que participam de esportes de contato, (2) tendo-se em conta os inúmeros fatores etiológicos, torna-se difícil estabelecer medidas preventivas, (3) o uso de protetores bucais confeccionados nos consultórios odontológicos tem diminuído significativamente a incidência de traumatismos dentários.

Em um artigo sobre a odontologia exercida nos clubes de futebol do Brasil, no ano de 2002, LIMA $^{55}$ comentou que vários casos relatados pela imprensa esportiva nacional e mundial apontam para a queda de produção, de rendimento e de performance, quando a saúde do jogador é afetada. No entanto, quando de trata de manifestações bucais que muitas vezes passam despercebidas e, por isso mesmo, evoluem para casos críticos. 
Ainda em 2002, BARBERINI; AUN; CALDEIRA ${ }^{13}$ pesquisaram a incidência de injúrias orofaciais e utilização de protetores bucais em 760 atletas de diversos esportes de contato. Os autores concluíram que a maioria dos atletas não usam protetores bucais, gerando uma incidência muito alta de injúrias orofaciais, e quando o fazem, preferem os do tipo II (feitos na boca), a não utilização deste equipamento está relacionada a adaptação e retenção, gerando dificuldade de respiração, principal fator de resistência ao uso, cabendo ao Cirurgião-Dentista orientar e esclarecer aos pais, técnicos, mestres, dirigentes, presidentes de federações e outros profissionais do esporte, sobre a prevenção de traumatismos dentários e o uso do protetor bucal, principalmente quando forem crianças e adolescentes.

RODRIGUES ${ }^{75}$, em 2003, revisou a literatura e concluiu que: 1) No Brasil são raros os estudos epidemiológicos sobre traumatismos bucodentários na prática esportiva, fazendo-se necessário um levantamento das condições de saúde bucal dos atletas. 2) É importante que os jovens envolvidos em exercícios físicos e esportes de contato disponham de proteção mais adequada. 3) Os tipos de traumatismos bucais mais freqüentes durante a prática esportiva são as fraturas coronárias e os deslocamentos dentários. 4) O uso de protetores bucais, preferencialmente os confeccionados sob medida, reduzem consideravelmente a prevalência de lesões buco-dentárias. 5) Poucos desportistas possuem informação sobre prevenção dos acidentes traumáticos envolvendo a dentição. 6) Os Cirurgiões-Dentistas precisam promover campanhas de conscientização, 
junto a dirigentes, treinadores e atletas, sobre a prevenção dos traumatismos orofaciais durante as suas atividades esportivas. 7) Os Cirurgiões-Dentistas por sua vez, devem possuir conhecimento suficiente para orientar os atletas sobre o tipo de proteção mais eficaz e adequada para cada esporte. 8) Os clubes, associações esportivas e academias deveriam possuir dentistas em seus quadros de profissionais para promover a saúde bucal dos seus atletas, implantar programas contra traumatismos dentários e tratar os casos de urgência odontológica.

Também em 2003, BARBERINI ${ }^{12}$ avaliou a influência do uso de diferentes tipos de protetores bucais no rendimento físico de atletas, quantificando de maneira precisa a ventilação pulmonar, consumo de oxigênio e produção de dióxido de carbono dos atletas, através de teste de potência aeróbica (eroespirométricos). Os protetores utilizados na pesquisa foram o do tipo II pré-fabricado (termo ajustáveis) e o do tipo III feito sob medida (individualizado). Foram analizados 14 atletas, sendo 12 do sexo masculino e 2 do sexo feminino, todos membros de equipes amadoras e profissionais de diversas categorias, sendo sua maioria praticante de esportes de contato, com idade média variando dos 17 a 41 anos. Os exames foram realizados em três fases: atleta sem protetor bucal, com protetor tipo II e com protetor tipo III .Os resultados obtidos demonstraram que os atletas que utilizaram os protetores do tipo III (individualizados) tiveram um desempenho melhor quanto ao consumo e equivalente ventilatório de oxigênio, chegando a um rendimento equivalente aos atletas 
sem protetor: em contrapartida os atletas que utilizaram o tipo II (Termoajustáveis) tiveram um menor desempenho com queda de rendimento físico.

De acordo com BUISCHI ${ }^{17}$, em 2004, a ingestão de produtos ácidos como refrigerantes, bebidas energéticas e sucos de frutas industrializados, é a causa mais freqüente da erosão dentária. Segundo a autora, nos EUA, 36\% dos nadadores e $85 \%$ dos ciclistas apresentam erosão dentária. Isso ocorre por causa dos energéticos que são bastante usados por atletas para a reposição da água e dos eletrólitos perdidos durante atividades altamente aeróbicas. BUISCHI ${ }^{17}$ também informou que a erosão é causada pelo contato direto de bebidas ou alimentos ácidos com o dente, a única forma de preveni-la é evitar o uso freqüente desses produtos.

SCAPINI ${ }^{78}$, também em 2004, publicou que para um atleta profissional, a saúde bucal poderá assumir contornos decisivos no seu condicionamento, rendimento e recuperação. Contudo, a debilitação física provocada pelas doenças orais manifesta-se também nos atletas amadores. Segundo o autor as conseqüências das doenças bucais em atletas são: 1) perda de desempenho e, conseqüentemente, do rendimento, 2) maior predisposição para contrair lesões físicas, 3) dificuldade agravada para a recuperação de lesões físicas, 4) diminuição da capacidade aeróbica, 5) estafa e fadiga precoce, 6) sub-aproveitamento dos alimentos ingeridos e 7) queda da auto-estima. 
Segundo SOUZA ${ }^{79}$, também em 2004, o primeiro trabalho do dentista desportivo é conscientizar o atleta da importância de sua boca estar em condição de saúde para que seu organismo não sofra interferência de problemas bucais, causando um menor rendimento físico. Problemas como má oclusão, respiração bucal, ausência dental, desordens na articulação temporomandibular e focos infecciosos (problemas endodônticos, gengivais, cáries, raízes residuais) certamente trazem conseqüências prejudiciais ao bom funcionamento do organismo. Para a autora os prejuízos mais comuns nesses casos são o mau aproveitamento do alimento ingerido, pela deficiência na mastigação e digestão; maior facilidade para ter lesões e maior dificuldade para a recuperação, pois o sistema de defesa já estará "ocupado" com os problemas bucais; diminuição da capacidade aeróbia; estafa e fadiga precoce. Estes danos se manifestam no atleta através da queda em seu desempenho e menor rendimento. É muito importante que o atleta passe por uma avaliação feita por um profissional com visão esportiva, pois se for detectado algum problema o tratamento deverá ser executado dentro da sua realidade. Detalhes como escolher o momento ideal para o início e término dos procedimentos, respeitando o seu calendário de competições, e o cuidado no uso de medicamentos que possam trazer alterações no exame antidoping podem ser esquecidos por profissionais não familiarizados com a Odontologia Desportiva. 
3 PROPOSIÇÃO 


\section{PROPOSIÇÃO}

O propósito deste estudo foi o de avaliar o padrão de conhecimento

e consciência dos atletas amadores da Cidade de Bauru-SP, relacionado aos cuidados de saúde bucal. 
4 Material e Método 


\section{MATERIAL E MÉTODO}

\subsection{MATERIAL}

Para realização desta pesquisa foi elaborado um questionário (ANEXO 1) abrangente, simples e de fácil compreensão, abordando questões como:

- Idade;

- Esporte praticado;

- Ocorrência de traumatismos dentários e orientações de prevenção quanto a estas injúrias;

- Conhecimento, uso, tipo, e como adquiriu o protetor bucal;

- Deixar de treinar ou jogar por problema dentário;

- Importância da presença do Cirurgião-Dentista no clube;

- Uso, compartilhamento, identificação pelo sabor, marca e motivo da escolha do creme dental;

- Número escovações por dia;

- Uso e número que vezes que passa fio dental ao dia;

- Uso e número que vezes que usa bochechos ao dia;

- Cor, tipo, troca e quem compra a escova de dentes;

- Medo de dentista;

- Quem e motivo que leva o atleta a tratar dos seus dentes;

- Periodicidade das visitas ao consultório odontológico. 


\subsection{MÉTODO}

Foram entrevistados 36 atletas, sendo 15 do sexo masculino e 21 do sexo feminino, todos membros de equipes amadoras assistidas pela SEMEL (Secretaria Municipal de Esporte e Lazer) da cidade de Bauru-SP, das modalidades: boxe, capoeira, futebol e voleibol, com média de idade entre 16 e 28 anos. Foi assinado por eles um termo de consentimento livre esclarecido (ANEXO 2), por escrito, autorizando a aplicação dos questionários.

Seis meses antes de responderem o questionário, os atletas foram convidados a assistir a uma palestra sobre Odontologia Esportiva, no salão nobre da Faculdade de Odontologia de Bauru, ministrada pelo autor da pesquisa.

Os atletas do boxe, capoeira e voleibol responderam ao questionário nos locais de treino, enquanto as atletas do futebol preencheram o questionário na clínica odontológica da Faculdade de odontologia de Bauru USP, situada na Casa do Garoto Rogacionista.

Os dados coletados foram submetidos à análise estatística descritiva utilizando-se freqüências relativa e absoluta. 
5 RESULTADOS 


\section{RESULTADOS}

Após a coleta dos dados contidos nos questionários respondidos

pelos 36 atletas, foram obtidos os seguintes resultados, que serão demonstrados através de figuras e tabelas, em três partes:

a) Participação quanto ao gênero e esporte;

b) Conhecimentos sobre protetores bucais;

c) Higiene bucal do atleta;

d) Relação atleta / Cirurgião-Dentista.

\subsection{Participação quanto ao gênero e esporte}

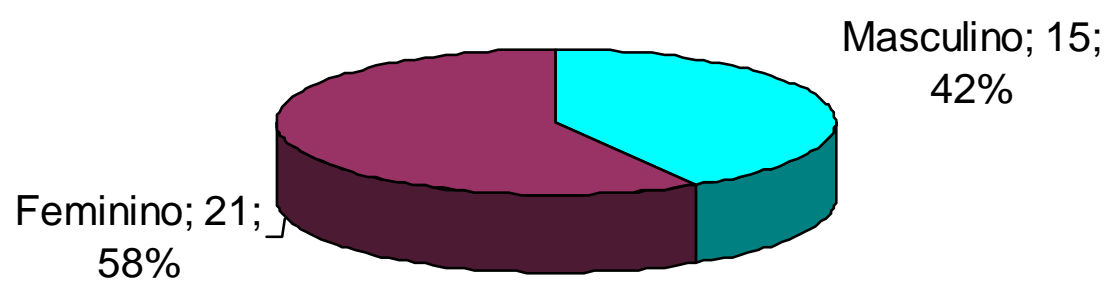

FIGURA 1 - Apresenta a participação dos atletas quanto ao gênero 


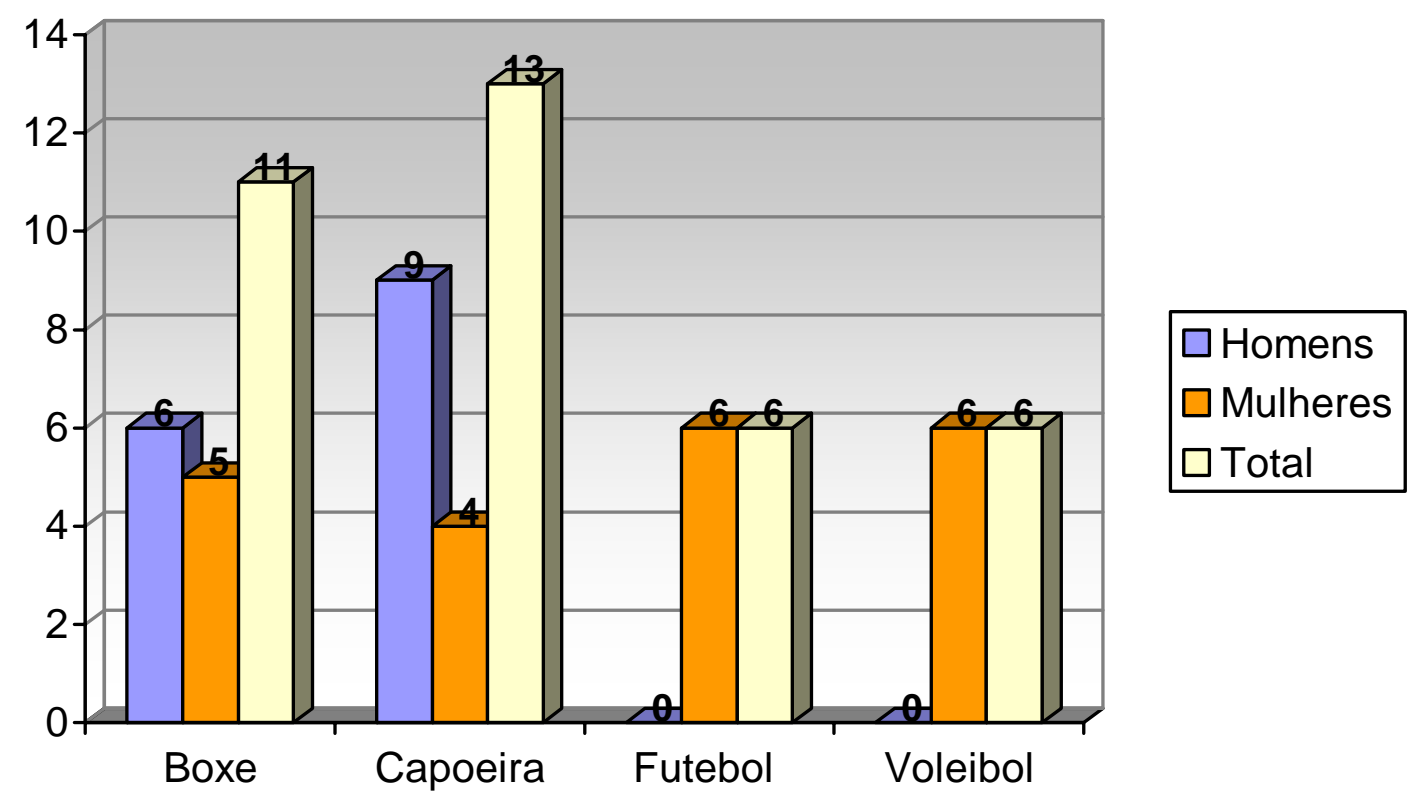

FIGURA 2 - Apresenta a participação dos atletas por esporte

\section{Observacão:}

a) Não houve participação de atletas do sexo masculino do futebol e voleibol, pois os mesmos receberam e não devolveram o termo de consentimento da pesquisa; 


\subsection{Conhecimentos sobre os protetores bucais}

A figura 3 contém os dados referentes ao sofrimento de traumatismos dentários sofridos pelos atletas.

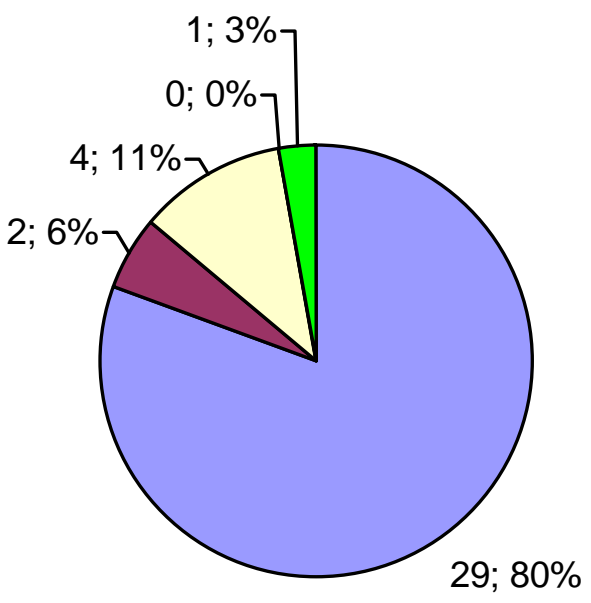

$\square$ Nunca

$\square$ Apenas pancada

$\square$ Fratura

$\square$ Perda total de dente

(s)

$\square$ Não respondeu

FIGURA 3 - Já sofreu traumatismo dentário praticando esporte? 
A figura 4, a seguir, apresenta o conhecimento dos atletas quanto aos protetores bucais.

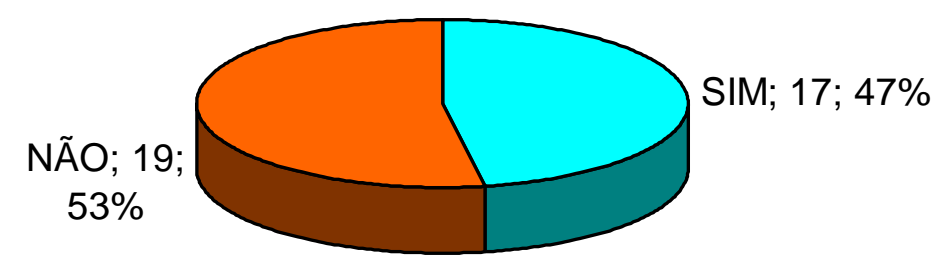

FIGURA 4 - Você conhece os protetores bucais?

A figura 5 apresenta os resultados obtidos quanto ao uso de protetores bucais pelos 17 atletas que responderam sim (conhecem os protetores bucais) mostrados no gráfico anterior. 


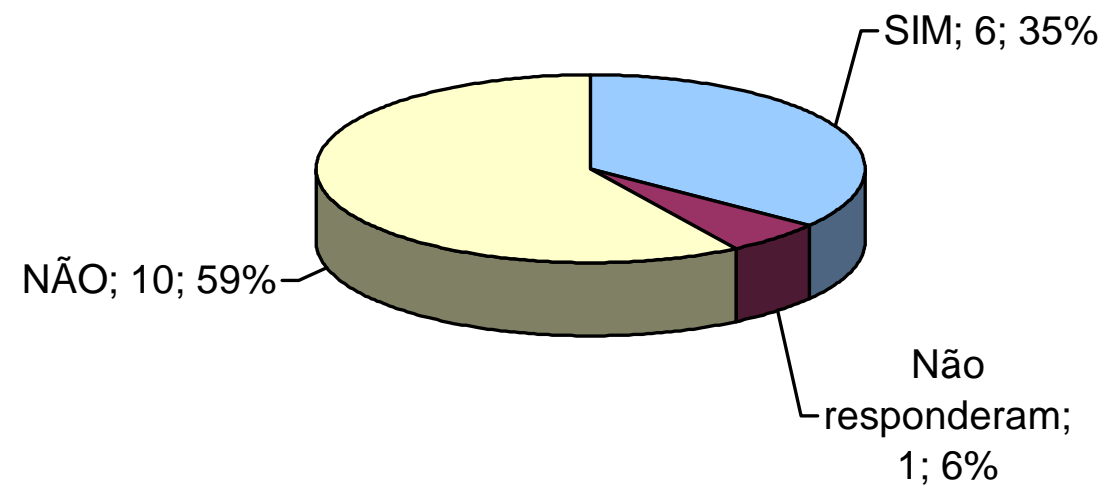

FIGURA 5 - Uso de protetores bucais pelos atletas que disseram conhecer os protetores bucais

A figura 6 apresenta os resultados obtidos quanto ao uso de protetores bucais pelos os atletas que participaram da pesquisa.

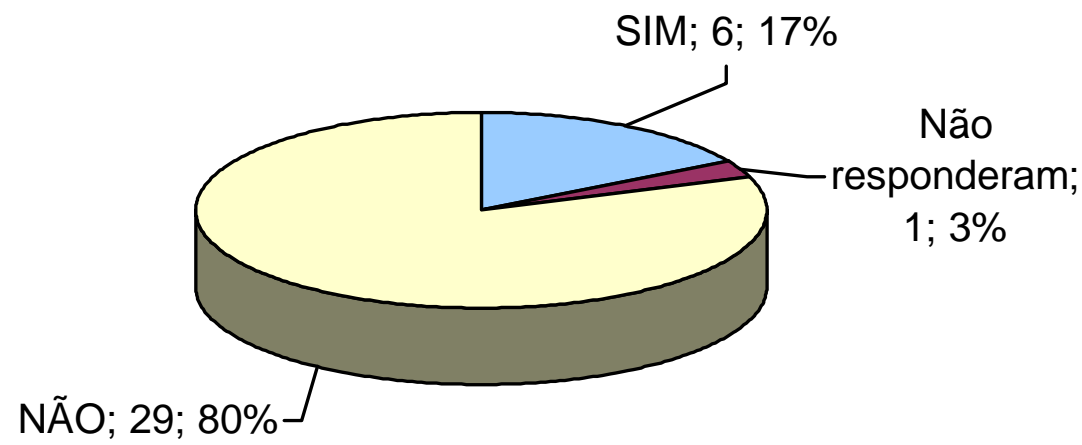

FIGURA 6 - Uso de protetores bucais pelos atletas 
A figura 7 mostra o tipo de protetor bucal utilizado pelos 6 atletas que responderam que usam esta proteção, conforme apresentado nas figuras 5 e 6 .

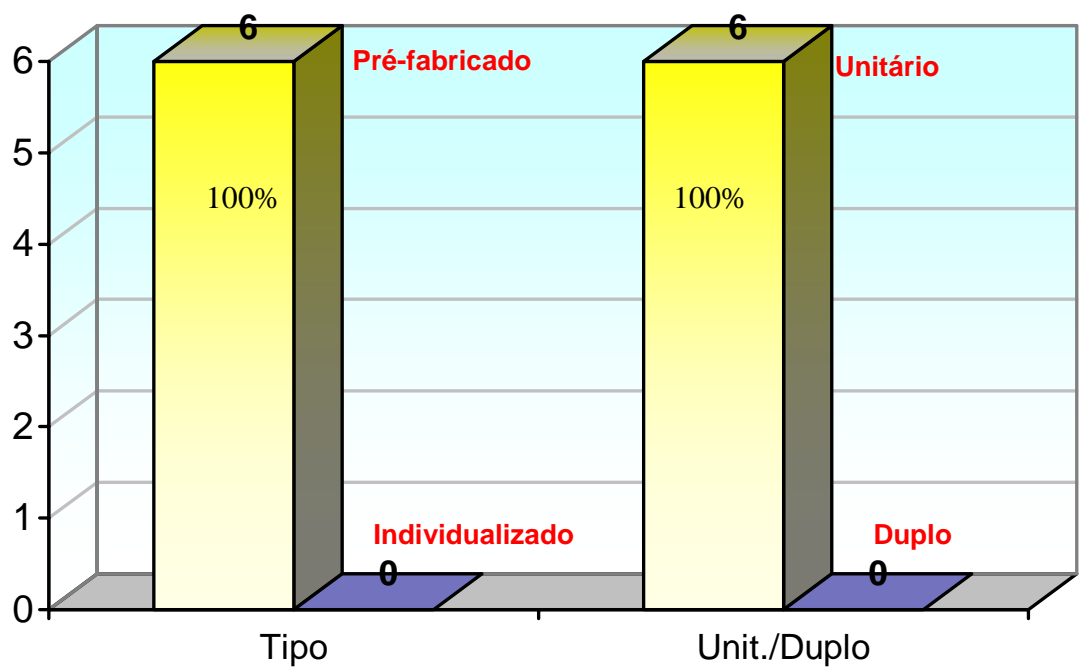

FIGURA 7 - Tipo de protetor bucal utilizado pelos atletas

\section{Observação:}

a) Nenhum atleta relatou usar protetor bucal duplo ou fabricado por um CirurgiãoDentista. 
A figura 8 mostra como foram adquiridos os protetores bucais dos 6 atletas que responderam que usam esta proteção, conforme apresentado nas figuras 5 e 6.

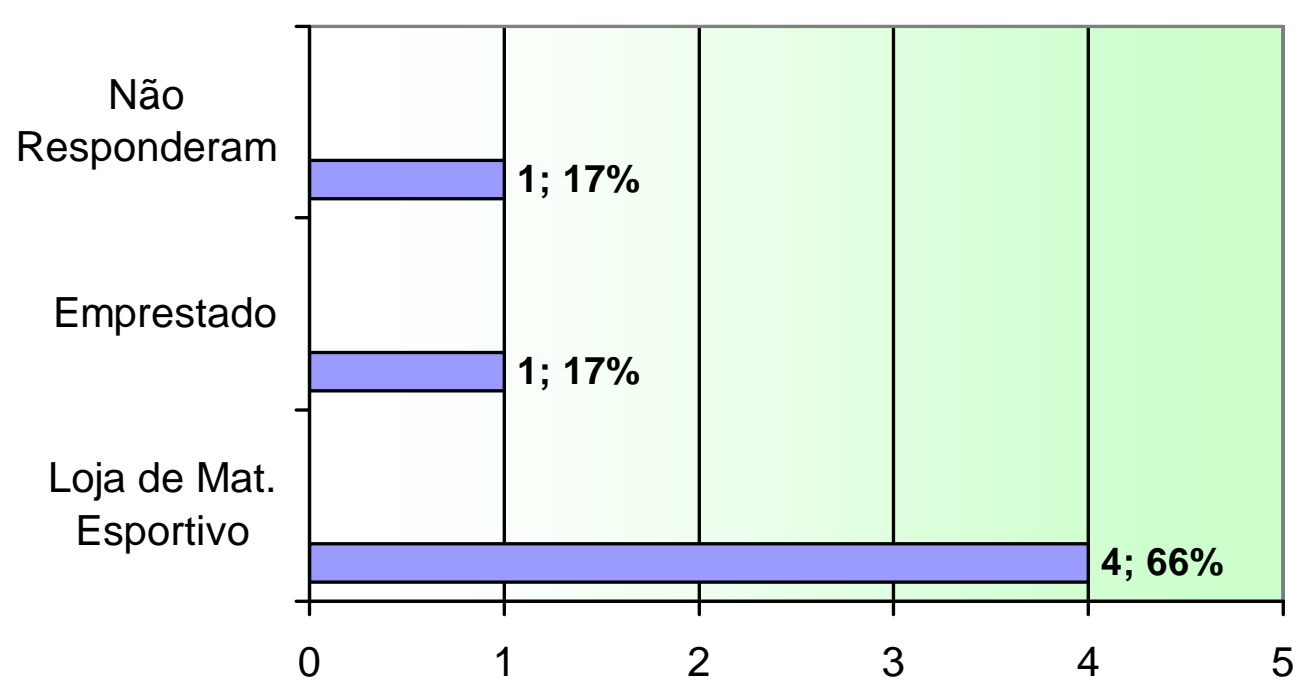

FIGURA 8 - Como foram adquiridos os protetores bucais 
A figura 9 apresenta os dados referentes ao uso de protetor bucal, emprestado por colega.

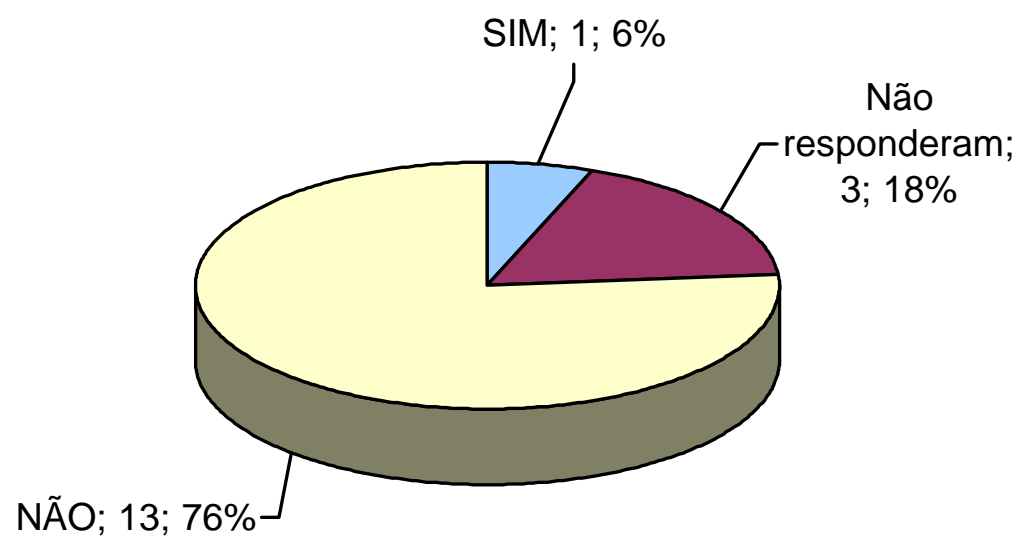

FIGURA 9 - Uso de protetores bucais emprestados

\section{Observação:}

a) Apenas um (boxe) dos 17 atletas que responderam que conheciam os protetores bucais, já usou protetor bucal emprestado por um colega. 
A figura 10 a seguir, mostra os resultados referentes à falta de atletas a treinos, jogos ou competições devido a problemas dentários.

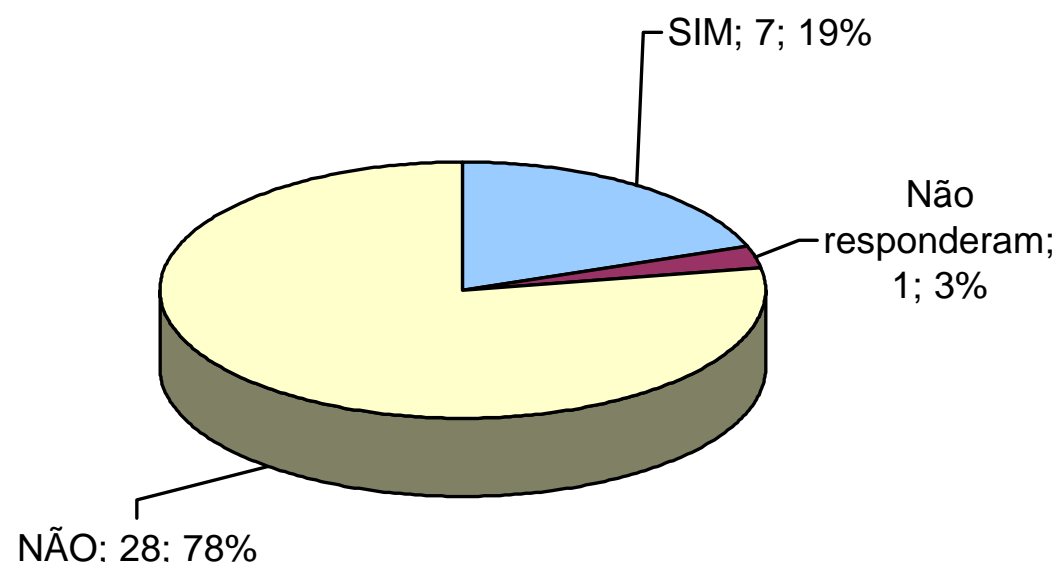

NÃO; $28 ; 78 \%$

FIGURA 10 - Falta a treinos, jogos ou competições devido a problemas dentários

\section{Observacões:}

a) Apenas um atleta não respondeu;

b) Cinqüenta por cento das atletas do voleibol já deixou de treinar por problemas dentários;

c) A capoeira mostrou que $23 \%$ dos atletas já foram prejudicados por problemas na boca;

d) O boxe não apresentou atletas que deixaram de treinar ou jogar devido a um problema dentário. 
A figura 11 contém os dados referentes à opinião dos sujeitos da pesquisa, referente a uma boca com problemas poder prejudicar a capacidade do atleta.

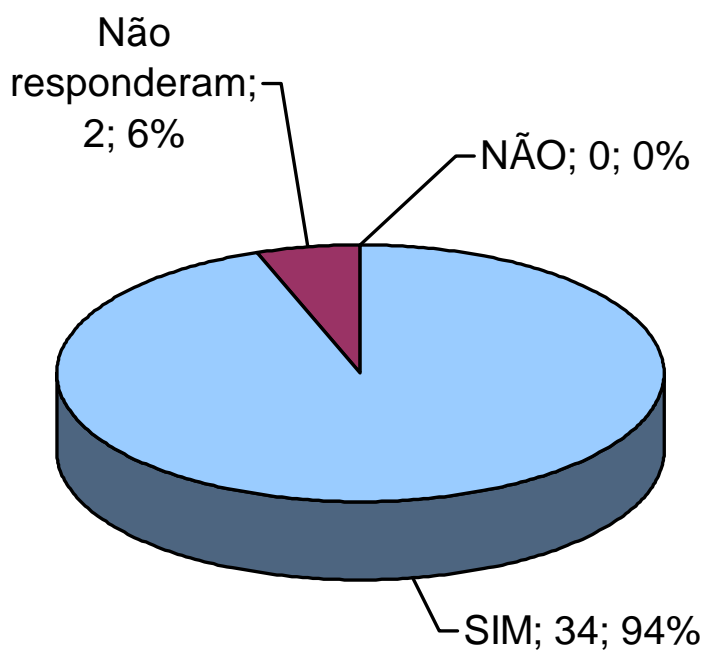

FIGURA 11 - Opinião dos atletas quanto a uma boca com problemas poder prejudicar a capacidade deles

\section{Observação:}

a) Nenhum atleta respondeu a alternativa Não; 


\subsection{Higiene bucal do atleta}

As tabelas de números 1 a 21 referem-se ao padrão de higiene bucal dos atletas.

TABELA 1 - Apresenta o compartilhamento do uso do mesmo creme dental, por atletas e familiares (em casa)

\begin{tabular}{ccc} 
& Freq. Absoluta & Freq. Relativa \\
\hline SIM & 14 & $39 \%$ \\
NÃO & 22 & $61 \%$ \\
\hline Total & 36 & $100 \%$ \\
\hline
\end{tabular}

TABELA 2 - Referente à compra do creme dental pelo atleta

\begin{tabular}{ccccc|cc} 
& Boxe & Capoeira & Futebol & \multicolumn{1}{c}{ Voleibol } & F. Absoluta & F. Relativa \\
\hline SIM & 3 & 6 & 3 & 1 & 13 & $36 \%$ \\
NÃO & 8 & 7 & 3 & 5 & 23 & $64 \%$ \\
\hline Total & 11 & 13 & 6 & 6 & 36 & $100 \%$ \\
\hline
\end{tabular}


TABELA 3 - Apresenta quem compra o dentifrício dos atletas que responderam que não compram o seu creme dental

\begin{tabular}{|c|c|c|}
\hline Quem compra? & Freq. Absoluta & Freq. Relativa \\
\hline Mãe & 5 & $22 \%$ \\
\hline Pai & 3 & $13 \%$ \\
\hline Pais & 2 & $9 \%$ \\
\hline Treinador & 1 & $4 \%$ \\
\hline Familiar & 1 & $4 \%$ \\
\hline Não Informaram & 11 & $48 \%$ \\
\hline Total & 23 & $100 \%$ \\
\hline
\end{tabular}

TABELA 4 - Referente ao uso freqüente do mesmo creme dental

\begin{tabular}{lccc}
\hline Esporte & SIM & NÃO \\
\hline Boxe & 5 & 6 \\
Capoeira & 5 & 8 \\
Futebol & 3 & 3 \\
Voleibol & 1 & 5 \\
& Total & 14 & 22 \\
\hline \multicolumn{2}{r|}{$\begin{aligned} \text { Freqüência } \\
\text { relativa }\end{aligned}$} & $39 \%$ & $61 \%$ \\
\hline
\end{tabular}


TABELA 5 - Marcas comerciais dos dentifrícios usados pelos atletas

\begin{tabular}{|r|c|c|}
\hline MARCAS & Freqüência absoluta & Freqüência relativa \\
\hline Colgate & 18 & $42 \%$ \\
\hline Sorriso & 12 & $28 \%$ \\
\hline Close Up & 9 & $21 \%$ \\
\hline Ice Fresh & 3 & $7 \%$ \\
\hline Natura & 1 & $2 \%$ \\
\hline Total & $\mathbf{4 3}$ & $\mathbf{1 0 0 \%}$ \\
\hline
\end{tabular}

Observações:

1. Os atletas podiam relatar mais de uma marca;

2. Onze atletas não responderam. 
TABELA 6 - Mostra os principais motivos que levam o atleta escolher um creme dental

\begin{tabular}{l|cc}
\hline Motivos & Freq. Absoluta & Freq. Relativa \\
\hline Sabor & 14 & $37 \%$ \\
Preço baixo & 11 & $29 \%$ \\
Cor & 1 & $3 \%$ \\
Perfume & 1 & $3 \%$ \\
Propaganda & 4 & $11 \%$ \\
Consistência & 0 & $0 \%$ \\
Maior disponibilidade no comércio & 1 & $3 \%$ \\
Indicação do Dentista & 4 & $11 \%$ \\
Outro & 1 & $3 \%$ \\
\hline
\end{tabular}

Observações:

1. Os atletas podiam marcar mais de um motivo;

2. Trinta e cinco responderam;

3. Um único atleta que marcou a opção outro, respondeu: "É o que gostamos de usar"; 
TABELA 7 - Apresenta quantas vezes os atletas escovam os dentes ao dia

\begin{tabular}{|c|c|c|}
\hline$N^{\circ}$ de vezes & Freq. Absoluta & Freq. Relativa \\
\hline Uma & 1 & $3 \%$ \\
\hline Duas & 3 & $8 \%$ \\
\hline Três & 23 & $64 \%$ \\
\hline Mais de três & 9 & $25 \%$ \\
\hline Total & 36 & $100 \%$ \\
\hline
\end{tabular}

TABELA 8 - Refere-se à identificação do creme dental apenas pelo sabor

\begin{tabular}{ccc} 
& Freq. Absoluta & Freq. Relativa \\
\hline SIM & 5 & $14 \%$ \\
NÃO & 31 & $86 \%$ \\
\hline Total & 36 & $100 \%$ \\
\hline
\end{tabular}

Observação: Dos cinco atletas que afirmaram conhecer o creme dental apenas pelo sabor, apenas um revelou as marcas que conseguia identificar (Colgate, Sorriso). 
TABELA 9 - Apresenta o número de atletas que fazem uso do fio dental

\begin{tabular}{ccc} 
& Freq. Absoluta & Freq. Relativa \\
\hline SIM & 18 & $50 \%$ \\
NÃO & 18 & $50 \%$ \\
\hline Total & 36 & $100 \%$ \\
\hline
\end{tabular}

TABELA 10 - Mostra quantas vezes os atletas usam fio dental ao dia

\begin{tabular}{|c|c|c|}
\hline$N^{o}$ de vezes & Freq. Absoluta & Freq. Relativa \\
\hline Uma & 9 & $49 \%$ \\
\hline Duas & 5 & $28 \%$ \\
\hline Três & 3 & $17 \%$ \\
\hline Mais de três & 1 & $6 \%$ \\
\hline Total & 18 & $100 \%$ \\
\hline
\end{tabular}

Observação: Os dados da tabela acima são referentes aos atletas que responderam "sim", conforme foi mostrado na tabela 9. 
TABELA 11 - Apresenta as justificativas pelo não uso do fio dental

\begin{tabular}{l|cc}
\hline Motivo & Freq. Absoluta & Freq. Relativa \\
\hline Não sei usar & 1 & $6 \%$ \\
Acho ruim & 4 & $22 \%$ \\
Não conheço & 1 & $6 \%$ \\
Nunca usei & 3 & $17 \%$ \\
Preguiça & 7 & $38 \%$ \\
Não Responderam & 2 & $11 \%$ \\
\hline \multicolumn{2}{r|}{ Total } & $\mathbf{1 8}$ \\
\hline
\end{tabular}

Observação: Os dados da tabela acima são referentes aos atletas que responderam "não", conforme foi mostrado na tabela 9. 
TABELA 12 - Mostra as justificativas pelo não uso do fio dental (por esporte)

\begin{tabular}{l|cccccc}
\hline Motivo & Boxe & Capoeira & Futebol & Voleibol & $\begin{array}{c}\text { Freq. } \\
\text { Absoluta }\end{array}$ & $\begin{array}{c}\text { Freq. } \\
\text { Relativa }\end{array}$ \\
\hline Não sei usar & 1 & - & - & - & 1 & $6 \%$ \\
Acho ruim & 1 & 2 & 1 & - & 4 & $22 \%$ \\
Não conheço & - & 1 & - & - & 1 & $6 \%$ \\
Nunca usei & - & 2 & 1 & - & 3 & $17 \%$ \\
Preguiça & 3 & 2 & 1 & 1 & 7 & $38 \%$ \\
Não & - & - & 1 & 1 & 2 & $11 \%$ \\
Responderam & & & & & & \\
\hline \multicolumn{1}{c}{ Total } & $\mathbf{5}$ & $\mathbf{7}$ & $\mathbf{4}$ & $\mathbf{2}$ & $\mathbf{1 8}$ & $\mathbf{1 0 0 \%}$ \\
\hline
\end{tabular}

TABELA 13 - Refere-se ao uso de bochechos pelos atletas

\begin{tabular}{c|cc}
\hline & Freqüência Absoluta & Freqüência Relativa \\
\hline SIM & 16 & $44 \%$ \\
NÃO & 20 & $56 \%$ \\
\hline Total & 36 & $\mathbf{1 0 0 \%}$ \\
\hline
\end{tabular}


TABELA 14 - Refere-se ao uso de bochechos pelos atletas (por esporte)

\begin{tabular}{cccccccc}
\hline & Boxe & Capoeira & Futebol & Voleibol & $\begin{array}{c}\text { Freqüência } \\
\text { Absoluta }\end{array}$ & $\begin{array}{c}\text { Freqüência } \\
\text { Relativa }\end{array}$ \\
\hline SIM & 2 & 8 & 3 & 3 & 16 & $44 \%$ \\
NÃO & 9 & 5 & 3 & 3 & 20 & $56 \%$ \\
\hline Total & $\mathbf{1 1}$ & $\mathbf{1 3}$ & $\mathbf{6}$ & $\mathbf{6}$ & $\mathbf{3 6}$ & $\mathbf{1 0 0 \%}$ \\
\hline
\end{tabular}

\section{Observações:}

1. O boxe apresentou o menor número de usuários dos bochechos (18\%), enquanto a capoeira mostrou o melhor resultado (62\%).

2. O futebol e o voleibol apresentaram um equilíbrio entre usuários (50\%) e não usuários de bochechos (50\%). 
TABELA 15 - Apresenta o número de vezes que os atletas usam o bochecho ao dia

\begin{tabular}{r|cccc|cc}
\hline Vezes & Boxe & Capoeira & Futebol & Voleibol & $\begin{array}{c}\text { Freqüência } \\
\text { Absoluta }\end{array}$ & $\begin{array}{c}\text { Freqüência } \\
\text { Relativa }\end{array}$ \\
\hline Uma & 2 & 8 & 1 & 2 & 13 & $\mathbf{8 1 \%}$ \\
Duas & - & - & 2 & 1 & 3 & $19 \%$ \\
Três & - & - & - & - & 0 & $0 \%$ \\
Mais de 3 & - & - & - & - & 0 & $0 \%$ \\
\hline Total & 2 & 9 & 3 & 3 & 16 & $100 \%$ \\
\hline
\end{tabular}

\section{Observações:}

1. As alternativas três e mais de três não foram marcadas por nenhum atleta.

2. A maioria dos atletas que usa o bochecho, realiza esta ação uma vez ao dia. 
TABELA 16 - Refere-se aos motivos pelos quais os atletas não usam o bochecho

\begin{tabular}{r|cc}
\hline Mortivos & $\begin{array}{c}\text { Freqüência } \\
\text { Absoluta }\end{array}$ & $\begin{array}{c}\text { Freqüência } \\
\text { Relativa }\end{array}$ \\
\hline Nunca usei & 3 & $15 \%$ \\
Não conheço & 1 & $5 \%$ \\
Não gosto & 5 & $25 \%$ \\
Outro & 4 & $20 \%$ \\
Sem resposta & 7 & $35 \%$ \\
\hline Total & $\mathbf{2 0}$ & $\mathbf{1 0 0 \%}$ \\
\hline
\end{tabular}

Observações:

1. Os outros motivos justificados pelos atletas foram:

- "Não tem em casa";

- "Falta de hábito".

2. Dois atletas não justificaram. 
TABELA 17 - Refere-se a quem compra as escovas de dentes dos atletas

\begin{tabular}{ccc} 
& Freq. Absoluta & Freq. Relativa \\
\hline O atleta & 28 & $78 \%$ \\
Outra pessoa & 8 & $22 \%$ \\
\hline Total & 36 & $100 \%$ \\
\hline
\end{tabular}

Observações:

1. Todos os atletas do futebol e do voleibol compram as suas escovas dentárias;

TABELA 18 - Apresenta as pessoas que compram as escovas dentárias dos atletas que afirmaram não comprar sua escova

\begin{tabular}{r|cccc}
\hline \multicolumn{1}{c|}{ Comprador } & Boxe & Capoeira & $\begin{array}{c}\text { Freqüência } \\
\text { Absoluta }\end{array}$ & $\begin{array}{c}\text { Freqüência } \\
\text { Relativa }\end{array}$ \\
\hline Pai & 2 & - & 2 & $26 \%$ \\
Mãe & 3 & - & 3 & $37 \%$ \\
Não responderam & 2 & 1 & 3 & $37 \%$ \\
\hline Total & 7 & 1 & $\mathbf{8}$ & $\mathbf{1 0 0 \%}$ \\
\hline
\end{tabular}


TABELA 19 - Mostra as cores da preferência para uma escova de dentes segundo os atletas

\begin{tabular}{|c|c|c|}
\hline CoR & Freqüência absoluta & Freqüência relativa \\
\hline Vermelha & 7 & $19 \%$ \\
\hline Azul & 11 & $31 \%$ \\
\hline Verde & 7 & $19 \%$ \\
\hline Branca & 8 & $22 \%$ \\
\hline Amarela & 1 & $3 \%$ \\
\hline Outra & 2 & $6 \%$ \\
\hline Total & 36 & $100 \%$ \\
\hline
\end{tabular}

TABELA 20 - Apresenta o tipo de escova utilizada pelos atletas (quanto à dureza das cerdas)

\begin{tabular}{|c|c|c|}
\hline Tipo de cerdas & Freq. Absoluta & Freq. Relativa \\
\hline Macia & 17 & $48 \%$ \\
\hline Extra-macia & 3 & $8 \%$ \\
\hline Média & 8 & $22 \%$ \\
\hline Dura & 3 & $8 \%$ \\
\hline Não Sabem & 5 & $14 \%$ \\
\hline Total & 36 & $100 \%$ \\
\hline
\end{tabular}


TABELA 21 - Refere-se ao período que um atleta usa uma escova de dentes

\begin{tabular}{l|cc}
\hline Período em meses & Freq. Absoluta & Freq. Relativa \\
\hline Um & 4 & $11 \%$ \\
Dois & 6 & $17 \%$ \\
Três & 18 & $50 \%$ \\
Mais de três & 8 & $22 \%$ \\
\cline { 2 - 2 } & & \\
\hline
\end{tabular}




\subsection{Relação Atleta / Cirurgião-Dentista}

As tabelas de números 22 a 33 são referentes à relação entre 0 atleta com o Cirurgião-Dentista.

TABELA 22 - Refere-se ao medo dos atletas de freqüentar a clínica odontológica

\begin{tabular}{ccc} 
& Freq. Absoluta & Freq. Relativa \\
\hline SIM & 10 & $28 \%$ \\
NÃO & 26 & $72 \%$ \\
\hline Total & 36 & $100 \%$ \\
\hline
\end{tabular}

TABELA 23 - Refere-se medo de freqüentar a clínica odontológica (Quanto ao gênero)

\begin{tabular}{ccc} 
& Freq. Absoluta & Freq. Relativa \\
\hline Masculino & 2 & $20 \%$ \\
Feminino & 8 & $80 \%$ \\
\hline Total & $\mathbf{1 0}$ & $\mathbf{1 0 0 \%}$ \\
\hline
\end{tabular}


TABELA 24 - Apresenta as justificativas do medo dos atletas para com o Cirurgião-Dentista

\begin{tabular}{l|cc}
\hline \multicolumn{1}{c|}{ Motivo } & Freq. Absoluta & Freq. Relativa \\
\hline Medo de anestesia & 1 & $10 \%$ \\
Medo do "motorzinho" & 3 & $30 \%$ \\
Medo de agulha & 2 & $20 \%$ \\
Medo de doer & 2 & $20 \%$ \\
"Uma dentista mexeu & 1 & $10 \%$ \\
no dente errado" & & $10 \%$ \\
Não Justificaram & 1 & $\mathbf{1 0 0 \%}$ \\
\hline
\end{tabular}

Observações:

1) Os atletas podiam relatar mais de um motivo por terem medo de dentistas.

2) Apenas um atleta não respondeu.

TABELA 25 - Justificativas dos atletas por NÃO terem medo do CirurgiãoDentista

\begin{tabular}{|c|c|c|}
\hline Motivo & Freq. Absoluta & Freq. Relativa \\
\hline "Sou acostumado" & 1 & $4 \%$ \\
\hline $\begin{array}{l}\text { "Porque não tem o } \\
\text { porquê" }\end{array}$ & 1 & $4 \%$ \\
\hline $\begin{array}{l}\text { "Ajuda a tratar meus } \\
\text { dentes" }\end{array}$ & 1 & $4 \%$ \\
\hline Não justificaram & 23 & $88 \%$ \\
\hline Total & 26 & $100 \%$ \\
\hline
\end{tabular}


TABELA 26 - Refere-se a quem cuida dos dentes dos atletas

\begin{tabular}{l|c|c}
\hline \multicolumn{1}{c|}{ Opções } & $\begin{array}{c}\text { Freqüência } \\
\text { Absoluta }\end{array}$ & $\begin{array}{c}\text { Freqüência } \\
\text { Relativa }\end{array}$ \\
\hline Dentista particular & 12 & $37 \%$ \\
Dentista do clube & 3 & $9 \%$ \\
Dentista do serviço público & 7 & $21 \%$ \\
Não vou ao Dentista & 11 & $33 \%$ \\
\hline \multicolumn{1}{c|}{ Total } & 33 & $100 \%$ \\
\hline
\end{tabular}

Observações:

1) Três atletas (9\%), não responderam.

2) Apesar dos clubes não terem Cirurgiões-Dentistas em seu quadro de funcionários, 3 atletas responderam que o "Dentista do clube" cuida dos seus dentes. 
TABELA 27 - Apresenta as justificativas dos atletas por não realizarem tratamento odontológico

\begin{tabular}{l|c|c}
\hline \multicolumn{1}{c|}{ Opções } & $\begin{array}{c}\text { Freqüência } \\
\text { Absoluta }\end{array}$ & $\begin{array}{c}\text { Freqüência } \\
\text { Relativa }\end{array}$ \\
\hline \hline "Falta de tempo" & 2 & $23 \%$ \\
"Vou quando dói" & 1 & $11 \%$ \\
"Nunca me preocupei" & 1 & $11 \%$ \\
"Não posso pagar" & 1 & $11 \%$ \\
"Preguiça" & 1 & $11 \%$ \\
"Vergonha dos dentes" & 1 & $11 \%$ \\
"Porque faz tempo que não vou" & 1 & $11 \%$ \\
"Não" & 1 & $11 \%$ \\
\hline
\end{tabular}

\section{Observações:}

1) A tabela 27 apresenta os dados referentes às justificativas dos 11 atletas que aparecem na tabela 26, na opção "não vou ao Dentista";

2) Apenas 4 atletas não justificaram;

3) Os atletas podiam escrever mais de uma justificativa. 
TABELA 28 - Mostra a periodicidade das visitas dos atletas ao consultório odontológico

\begin{tabular}{|c|c|c|}
\hline Opções & $\begin{array}{c}\text { Freqüência } \\
\text { Absoluta }\end{array}$ & $\begin{array}{l}\text { Freqüência } \\
\text { Relativa }\end{array}$ \\
\hline 1 mês & 2 & $7 \%$ \\
\hline 2 meses & 0 & $0 \%$ \\
\hline 3 meses & 1 & $4 \%$ \\
\hline 6 meses & 9 & $32 \%$ \\
\hline 1 ano & 4 & $14 \%$ \\
\hline Mais de um ano & 12 & $43 \%$ \\
\hline Total & 28 & $100 \%$ \\
\hline
\end{tabular}

Observações:

1) Oito atletas não responderam. 
TABELA 29 - Mostra a periodicidade das visitas dos atletas ao consultório odontológico (por esporte)

\begin{tabular}{c|cccc|cc}
\hline Opções & Boxe & Capoeira & Futebol & Voleibol & $\begin{array}{c}\text { Freqüência } \\
\text { Absoluta }\end{array}$ & $\begin{array}{c}\text { Freqüência } \\
\text { Relativa }\end{array}$ \\
\hline \hline 1 mês & - & 1 & - & 1 & 2 & $7 \%$ \\
2 meses & - & - & - & - & 0 & $0 \%$ \\
3 meses & - & - & 1 & - & 1 & $4 \%$ \\
6 meses & 2 & 2 & 1 & 4 & 9 & $32 \%$ \\
1 ano & 2 & 1 & - & 1 & 4 & $\mathbf{1 4 \%}$ \\
Mais de & 2 & 7 & 3 & - & 12 & $43 \%$ \\
um ano & & & & & & \\
\hline Total & 6 & 11 & 5 & 6 & 28 & $100 \%$ \\
\hline
\end{tabular}

Observações:

1) Conforme foi explicado na tabela 28, oito atletas não responderam. Sendo 5 do boxe, 2 da capoeira e 1 do futebol.

2) Todas as participantes do voleibol responderam. 
TABELA 30 - Apresenta os principais motivos que levam os atletas ao consultório odontológico

\begin{tabular}{l|cc}
\hline \multicolumn{1}{c|}{ Motivos } & $\begin{array}{c}\text { Freqüência } \\
\text { Absoluta }\end{array}$ & $\begin{array}{c}\text { Freqüência } \\
\text { Relativa }\end{array}$ \\
\hline Mau Hálito & 0 & $0 \%$ \\
Dor & 9 & $27 \%$ \\
Prótese & 1 & $3 \%$ \\
Traumatismo & 1 & $3 \%$ \\
Sangramento & 1 & $3 \%$ \\
Gosto de ir ao dentista & 2 & $6 \%$ \\
Acho meus dentes feios & 4 & $12 \%$ \\
Outros motivos & 15 & $46 \%$ \\
\hline
\end{tabular}

Observações:

1) Apenas 3 atletas não responderam.

2) Quinze atletas marcaram a opção outros.

3) Os outros motivos serão mostrados na tabela 31. 
TABELA 31 - Outros motivos que levam os atletas ao consultório odontológico

\begin{tabular}{l|cc}
\hline \multicolumn{1}{c|}{ Outros motivos } & $\begin{array}{c}\text { Freqüência } \\
\text { Absoluta }\end{array}$ & $\begin{array}{c}\text { Freqüência } \\
\text { Relativa }\end{array}$ \\
\hline "Prevenção" & 4 & $26 \%$ \\
"Extração" & 1 & $7 \%$ \\
"Por uma série de fatores" & 1 & $7 \%$ \\
"Estética" & 1 & $7 \%$ \\
"Higiene bucal" & 1 & $7 \%$ \\
"Gengiva dolorida" & 1 & $7 \%$ \\
Não Justificaram & 6 & $39 \%$ \\
\hline & Total & $\mathbf{1 5}$ \\
\hline
\end{tabular}

TABELA 32 - Recebimento de informações de um Cirurgião-Dentista sobre prevenção de traumatismos dentários

\begin{tabular}{ccc} 
& Freq. Absoluta & Freq. Relativa \\
\hline SIM & 11 & $31 \%$ \\
NÃO & 25 & $69 \%$ \\
\hline Total & $\mathbf{3 6}$ & $\mathbf{1 0 0 \%}$ \\
\hline
\end{tabular}


TABELA 33 - Apresenta a importância dada pelos atletas quanto à presença de um Cirurgião-Dentista em seu clube

\begin{tabular}{|c|c|c|}
\hline Outros motivos & $\begin{array}{c}\text { Freqüência } \\
\text { Absoluta }\end{array}$ & $\begin{array}{c}\text { Freqüência } \\
\text { Relativa }\end{array}$ \\
\hline Extremamente Importante & 23 & $66 \%$ \\
\hline Muito Importante & 4 & $11 \%$ \\
\hline Importante & 8 & $23 \%$ \\
\hline Desnecessária & 0 & $0 \%$ \\
\hline Não precisa & 0 & $0 \%$ \\
\hline Total & 35 & $100 \%$ \\
\hline
\end{tabular}

Observação:

1) Apenas um atleta não respondeu. 
6 Discussão 


\section{DISCUSSÃO}

O estado dos dentes constitui um dos aspectos mais visíveis da saúde da pessoa, existindo uma relação direta com a atuação esportiva.

Quem pratica esportes deve ter condições físicas adequadas para competir sem riscos de traumas ou diminuição do rendimento físico. Uma simples dor de dente, por mais sutil que seja, pode fazer a diferença em um importante jogo de futebol ou uma prova decisiva de atletismo ou natação, por exemplo. Isto porque a saúde da boca envolve mecanismos que abrangem várias funções do corpo, como respiração e circulação.

A Odontologia Esportiva é o tratamento e, principalmente, a prevenção de traumas orofaciais relacionados à prática esportiva $\left(\right.$ PADILLA $\left.^{64}\right)$. É importante frisar que a área mais atingida na prática de esportes é a orofacial, muito comum em esportes de contato ou impacto. $\left(\right.$ DREYER $^{28}$, KONNIS $^{49}$, RANALLI; LANCASTER $\left.^{72}\right)$

O Cirurgião-dentista especialista em Odontologia Esportiva tem a responsabilidade de fornecer informações aos treinadores e técnicos, informações sobre o procedimento de emergência nestes acidentes $\left(D_{R E Y E R}{ }^{28}\right)$, e principalmente conscientizá-los sobre a prevenção destas 
injúrias através da conscientização quanto ao uso de acessórios de segurança, como o protetor bucal para cada esporte.

A proteção das estruturas dentárias e orofaciais nos esportes de contato é alvo de inúmeros estudos que buscam cada vez mais o aprimoramento de técnicas, visando obter os menores índices possíveis de injúrias às estruturas mencionadas. (BARBERINI ${ }^{12}, \mathrm{BARBERINI}{ }^{13}$ )

A remoção da placa bacteriana é o principal objetivo da escovação dentária. Apesar de ser questionável a eficiência da escovação como medida isolada na prevenção da cárie, seu aspecto educacional é inegável, pois faz com que os indivíduos adquiram hábitos diários de cuidados com a saúde bucal (NORONHA et al. ${ }^{61}$ )

A atitude do profissional Cirurgião-Dentista em atuar de forma curativa, após a doença instalada, e não com uma postura preventiva, evitando que a doença apareça, formou através dos anos uma imagem de mutilador do profissional $\left(\mathrm{AMORIM}^{3}\right)$.

Sabe-se que a ansiedade e o medo gerados por certos procedimentos são fatores que devem ser levados em consideração frente a um tratamento dentário. Quando existe a necessidade de um ato cirúrgico, esse medo tende a aumentar, podendo até inviabilizar a execução do procedimento dentro do consultório odontológico (BARROS; LOPES ${ }^{14}$ ). 
Diante dessas óticas, avaliamos o conhecimento sobre protetores bucais, o padrão de higiene bucal e a relação atleta / Cirurgião-Dentista de 36 atletas amadores que são assistidos pela Secretaria de Esporte e Lazer (SEMEL), do município de Bauru-SP.

A relação entre o sexo masculino e o feminino quando a participação na pesquisa foi de 0,7:1. A freqüência relativa masculina foi $42 \%$ e a feminina 58\% (FIGURA 1). Sendo que não houve participação masculina do futebol e do voleibol (FIGURA 2).

Quanto à participação dos atletas por esporte, a capoeira participou com $35 \%$, seguida do boxe com $31 \%$, o futebol $17 \%$ e o voleibol também com $17 \%$.

Em relação aos atletas já terem sofrido algum traumatismo dentário durante a prática esportiva, a maioria respondeu que nunca sofreu (80\%), a fratura foi apontada por $11 \%$. Apenas pancada $6 \%$, perda total de dentes (avulsão dentária) 0\% e não responderam 3\% (FIGURA 3). Segundo a NATIONAL YOUTH SPORTS SAFETY FOUNDATION ${ }^{59}$ - NYSSF, uma fundação americana para prevenção de injúrias nos esportes, cada atleta de esportes de contato tem cerca de $10 \%$ de chances de sofrer contusões orofaciais durante uma sessão esportiva, ou 33\% a 56\% durante toda a sua carreira. 
Quanto ao conhecimento dos protetores bucais, menos da metade dos atletas (47\%) conhecem este aparato, contra 53\% que não conhecem (FIGURA 4). O percentual dos atletas que conhecem os protetores bucais esteve abaixo dos percentuais encontrados por PRIETO; DAVIDOWICZ; MOURA $^{69}$, em 1998.

A maioria dos atletas que responderam que conhece os protetores bucais, mostrado no gráfico 4, no quesito referente ao uso dessa proteção revelou que a maior parte desses competidores não o usa (59\%), seguido dos que usam (35\%), e não responderam (6\%) (FIGURA 5). Em relação a todos os participantes da pesquisa, o percentual dos que não usam protetor bucal foi de 80\% (FIGURA 6). Estes resultados estão muito próximos aos observados no estudo de BARBERINI; AUN; CALDEIRA ${ }^{13}$ (2002).

O tipo de protetor bucal utilizado pelos atletas é o pré-fabricado (ferve e morde) (100\%), unitário (100\%), usado no arco dentário superior (FIGURA 7). Esses equipamentos, segundo os competidores, foram adquiridos da seguinte forma: comprado em loja de material esportivo (66\%), emprestado (17\%) e não responderam (17\%) (FIGURA 8).

Quanto ao uso do protetor bucal de um colega, a maioria respondeu que não (76\%), enquanto $6 \%$ responderam sim. Dezoito por cento dos atletas deixaram de responder (FIGURA 9). Sem o uso desse aparato, um 
atleta tem 60 vezes mais riscos de ter seus dentes danificados, sendo o custo de uma fratura bem maior do que um protetor bucal confeccionado por um profissional (NYSSF ${ }^{59}$ ).

Em relação à falta aos treinos ou jogos e competições, por causa de problemas dentários, foram obtidos os seguintes resultados: não (78\%), sim (19\%) e não responderam (3\%) (FIGURA 10). A relação da saúde oral com a saúde geral é de fundamental importância para o desempenho dos competidores. Visto que as infecções de origem orofacial acabam refletindo a capacidade do atleta influindo negativamente no seu desempenho, sendo pois, incompatíveis com a vida profissional de cada um (RODRIGUES; SALES PERES; BASTOS ${ }^{76}$ ).

Com relação à opinião dos sujeitos da pesquisa quando perguntados se uma boca com problemas pode prejudicar a capacidade do atleta, a maioria respondeu sim (94\%), sem resposta (6\%) e não (0\%) (FIGURA 11).

Na segunda parte do questionário foram feitas perguntas referentes à higiene bucal dos atletas, já que a prevenção não se resume só ao uso de protetores bucais, mas também a profilaxia de prejuízos à cavidade oral ou ao tratamento de tais manifestações que, direta ou indiretamente, possam comprometer a performance atlética. O padrão de higiene bucal faz parte de um conjunto de condutas familiares com reação às questões de saúde. 
Quanto ao compartilhamento do mesmo creme dental pelos atletas em suas residências, foi achado um dado interessante: $61 \%$ responderam não e 39\% sim (TABELA1).

Em relação à compra do creme dental, a maioria dos atletas não compra (64\%), enquanto 36\% compram esse dentifrício (TABELA 2). Quando foi perguntado aos sujeitos da pesquisa que responderam não comprar, quem compra o dentifrício por eles utilizado obtivemos as seguintes respostas: não informaram (48\%), Mãe (22\%), Pai (13\%), Pais (4\%), treinador (4\%) e família (4\%) (TABELA 3).

Os atletas foram questionados se sempre usavam o mesmo creme dental e a maioria respondeu não (61\%) enquanto 39\% dos competidores responderam sim (TABELA 4).

Os cremes dentais mais utilizados pelos atletas são: Colgate Colgate-Palmolive (33\%), Sorriso - Colgate-Palmolive (22\%), Close Up Unilever (17\%), Ice Fresh - Condor (6\%) e Natura - Natura (2\%) (TABELA 5). Como os dentifrícios acima citados não foram especificados, impossibilita-nos de apresentar a eficácia dos mesmos, baseada nos resultados da pesquisa de KUMIYAMA; KOGA-ITO ${ }^{51}$ (2004), onde foi analisado o desempenho de dentifrícios no combate a bactéria Streptococcus mutans, principal causadora das cáries dentárias. 
Diversos são os fatores que podem influenciar na escolha de um creme dental. Assim, ao selecionar a pasta de dentes, o indivíduo poderá considerar o sabor, o perfume, a cor, a apresentação comercial do creme dental, o preço, uma recomendação ou ainda o marketing vinculado ao produto. Em nossa pesquisa, quanto aos dados encontrados referentes aos principais motivos que levam um atleta a escolher seu creme dental, podemos observar que o sabor é o principal motivo, visto que os achados apresentaram: o sabor com 37\% da preferência, seguido do preço baixo com 29\%, propaganda e indicação do Cirurgião-Dentista com 11\% cada um, enquanto a cor, o perfume, e a maior disponibilidade ficaram empatados com 3\% da preferência dos competidores (TABELA 6). Por outro lado, apesar do sabor ser o principal motivo de escolha de um creme dental pelos atletas, apenas 14\% deles são capazes de reconhecer um dentifrício apenas pelo sabor. Destes $14 \%$, apenas um competidor revelou as marcas que conseguia identificar as marcas Colgate e Sorriso. (TABELA 8).

Em relação ao número de escovações dentárias ao dia, obtivemos os seguintes resultados: uma vez (3\%), duas vezes (8\%), três vezes (64\%) e mais de três vezes (25\%) (TABELA 7). Pelo observado, onze por cento dos atletas não realiza o número mínimo de escovações diárias recomendadas pelos Cirurgiões-Dentistas, que é três.

O uso diário de fio dental como complemento da escovação tem um efeito benéfico sobre a saúde gengival, uma vez que contribui para a 
prevenção de enfermidades gengivais, limpando áreas não alcançadas pela escova convencional. No entanto, seu uso é feito apenas por metade dos atletas (TABELA 9), que quando foram questionados sobre o número de vezes que usam o fio dental ao dia, obtivemos os seguintes dados: uma vez (49\%), duas vezes (28\%), três vezes (17\%) e mais de três vezes (6\%) (TABELA 10).

O não uso do fio dental foi justificado pelos competidores com os seguintes percentuais: não sei usar (6\%), acho ruim (22\%), não conheço (6\%), nunca usei (17\%) e a preguiça com 38\% foi o principal motivo. Onze por cento dos atletas que afirmaram não usar o fio dental deixaram de justificaram o motivo (TABELA 11). O esporte que apresentou mais participantes que não usam este produto é o futebol (TABELA 12).

O controle químico da placa bacteriana é um complemento importante na higiene bucal, na profilaxia e na terapia das infecções dentárias (CAVEZZI JUNIOR et al. ${ }^{19}$ ). Por esta razão, perguntamos aos competidores se eles faziam uso de algum bochecho, e obtivemos o seguinte resultado: $\operatorname{sim}(44 \%)$ e não (56\%) (TABELA 13). Quanto ao uso de bochechos o boxe com 18\%, foi o esporte que apresentou o menor número de usuários, enquanto a capoeira apresentou o melhor resultado (62\%) (TABELA 14). 
Em relação ao o número de vezes ao dia citado pelos os atletas que afirmaram fazer uso do bochecho, os resultados foram os seguintes: uma vez $(81 \%)$, duas vezes (19\%), três vezes $(0 \%)$ e mais de três vezes $(0 \%)$ (TABELA 15).

Os motivos pelos quais os atletas não usam algum bochecho, foram assim afirmados: nunca usei (15\%), não conheço (5\%), não gosto (25\%), outro motivo (20\%). Trinta e cinco por cento dos competidores que afirmaram não fazer uso de bochechos não responderam. Os outros motivos justificados pelos atletas foram: "não tem em casa" e "falta de hábito" (TABELA 16).

Quanto a compra da escova de dentes do atleta, a maioria (78\%) compra a sua própria escova, enquanto $22 \%$ tem sua escova comprada por outra pessoa (TABELA 17). Em relação à justificativa dos atletas que não compram suas escovas de dentes, obtivemos os seguintes dados referentes a quem as adquire: Pai (26\%), Mãe (37\%). Trinta e sete por cento não responderam quem compra (TABELA 18).

Em relação à cor das escovas de dentes utilizadas pelos competidores, a cor azul é a preferida (31\%), seguida da cor branca (22\%), verde e vermelha (19\%) cada uma, amarela (3\%) e outras cores (6\%). Os sujeitos da pesquisa não revelaram as outras cores (TABELA 19). 
No quesito referente ao grau de dureza das cerdas das escovas dentárias, encontramos os seguintes achados: as escovas de cerdas macias são usadas por $48 \%$ dos competidores, seguida pelas escovas com cerdas médias (22\%), cerdas extramacias (8\%), e cerdas duras (8\%). Quatorze por cento dos atletas não sabem o tipo (grau de dureza das cerdas) de sua escova (TABELA 20).

A escova ideal para dentes naturais deve ser macia ou extramacia. Para uma boa escovação dental, é necessário escovar as gengivas e as escovas duras, além de machucarem a gengiva, podem desgastar os dentes, provocando sensibilidade, e a retração gengival, que afeta a estética do sorriso e também provoca dor (TUMENAS ${ }^{82}$ ). Mais da metade dos competidores (56\%) usa escovas consideradas ideais.

Quanto ao período que um atleta usa uma escova dentária, os resultados foram os seguintes: $50 \%$ troca à escova a cada 3 meses, 22\% num período maior que 3 meses, $17 \%$ a cada 2 meses e $11 \%$ a cada mês (TABELA 21). Pesquisas mostram que os indivíduos, na sua grande maioria, trocam suas escovas em períodos superiores aos 3 meses de uso. (ABRAHAM et al. ${ }^{1}$, PANZERI et al. ${ }^{65}$ )

Segundo ABRAHAM et al. ${ }^{1}$, uma grande parte dos profissionais de Odontologia recomenda a troca de escovas dentais, a cada 3 meses, no 
entanto a durabilidade de uma escova varia em função dos diferentes fatores que incidem sobre ela durante seu uso.

PANZERI et al. ${ }^{65}$ publicaram que além da textura das cerdas, vários fatores podem interferir no desgaste das cerdas de uma escova dental, como o tempo de uso, a força empregada no ato da escovação, a freqüência, a técnica de escovação escolhida, o índice de deflexão das cerdas, o uso de aparelhos ortodônticos fixos, dentre outros .

No Brasil, o consumo per capita de escovas dentárias é considerado baixo. O brasileiro costuma comprar uma nova escova a cada 17 meses, enquanto o recomendável pelas autoridades de saúde bucal é de três meses $\left(\right.$ JOHNSON \& JOHNSON $\left.{ }^{45}\right)$. Nossos achados referentes ao tempo de uso de uma escova dentária se aproximam do recomendado pelas autoridades de saúde bucal.

Quanto ao medo de freqüentar a clínica odontológica, 72\% responderam não, enquanto $28 \%$ afirmaram ter medo de ir ao dentista (TABELA 22). Neste quesito as mulheres se mostraram mais temerosas com $80 \%$, e os homens mais encorajados, apresentado apenas $20 \%$ dos atletas que afirmaram ter medo de dentista (TABELA 23).

Os atletas puderam relatar de forma aberta seus motivos por terem medo de freqüentar o consultório odontológico, sendo encontrados as 
seguintes respostas: "medo do motorzinho" (30\%), "medo de agulha" (20\%), "medo de doer" (20\%), "medo de anestesia" (10\%) e "uma dentista mexeu no dente errado" (10\%) que foi um achado impressionante. Apenas um competidor não justificou a questão (TABELA 24).

Os poucos competidores (12\%), que afirmaram não ter medo de freqüentar o consultório odontológico relataram tais motivos. As justificativas foram as seguintes: "Sou acostumado" (4\%), "Porque não tem o porquê" (4\%), "Ajuda a tratar meus dentes" (4\%). Oitenta e oito por cento dos atletas não justificaram (TABELA 25).

No quesito referente a quem cuida dos dentes dos atletas, obtivemos os seguintes resultados: Cirurgião-Dentista particular (37\%), Cirurgião-Dentista do serviço público (21\%), Cirurgião-Dentista do clube (9\%). Trinta e três por cento dos competidores não vão ao Dentista. E 9\% não responderam a questão. Um dado obtido nos chamou atenção, visto que, apesar dos clubes não possuírem Cirurgiões-Dentistas em seu quadro de funcionários, $9 \%$ dos sujeitos da pesquisa responderam que o "Dentista do clube" cuida dos seus dentes (TABELA 26).

Em relação às justificativas dos competidores que disseram não realizar tratamento odontológico, a falta de tempo foi a mais citada com $23 \%$, enquanto as seguintes alternativas: "vou quando dói”, "Nunca me preocupei“, "Não posso pagar", "Preguiça", "Vergonha dos dentes", "Porque faz tempo 
que não vou", "Não", ficaram com $11 \%$ cada uma. Nesta questão os atletas podiam escrever mais de uma justificativa. Apenas 4 não justificaram. (TABELA 27).

Quanto à periodicidade das visitas ao consultório odontológico, obtivemos os seguintes achados: o período mais de 1 ano com $43 \%$ foi o mais citado pelos atletas, seguido pelo período de 6 meses com 32\%, 1 ano (14\%),1 mês (7\%), 3 meses (4\%) e enquanto o período de 2 meses que não foi citado. Oito atletas não responderam (TABELA 28). As praticantes do voleibol são as que passam menos tempo para freqüentar o consultório odontológico (TABELA 29).

Os principais motivos que levam os atletas a um consultório odontológico são: dor (27\%), acho meus dentes feios (12\%), gosto de ri ao Dentista (6\%), prótese (3\%), traumatismo (3\%), sangramento (3\%), e outros motivos (46\%) (TABELA 30). Em relação aos outros motivos que foram citados, a "prevenção" está em primeiro lugar com 26\%, seguido de "extração", "uma série de fatores", "estética", "higiene bucal", "gengiva dolorida", com 7\% cada um. Deixaram de justificar 39\% dos competidores (TABELA 31).

Os atletas foram questionados se já haviam recebido alguma informação referente à prevenção de traumatismos dentários, e a maioria (69\%) respondeu que não. (TABELA 32). Tal resultado já era esperado, em 
razão da Odontologia Esportiva ainda não ser uma especialidade no Brasil, conseqüentemente não são ministradas aulas nos cursos de graduação em Odontologia de nosso país. Diferente dos países nos quais este ramo do conhecimento odontológico já é efetivo, onde uma das funções atribuídas ao especialista nesta área, segundo DREYER ${ }^{28}$, é conscientizar atletas, treinadores e técnicos, sobre a prevenção destas injúrias através da orientação referente ao uso de acessórios de segurança, como o protetor bucal ideal para cada esporte.

Segundo $\operatorname{LIMA}^{54}$, a maioria dos clubes não possui consultório odontológico. Isto mostra que os padrões de saúde oral apresentado por atletas apontam para a falta de importância dada aos cuidados com a saúde dos atletas. O autor destaca que na maioria das vezes, o Departamento Médico dos clubes dão mais preferência, por exemplo, ao exame de sangue do que o odontológico do atleta. Por este comentário perguntou-se aos sujeitos da pesquisa qual a importância dada por eles, em relação à presença de um Cirurgião-Dentista na equipe acompanhando treinos e jogos. A opção extremamente importante foi a campeã com $66 \%$ da opinião dos competidores, em segundo foi a opção importante com 23\% e em terceiro a alternativa muito importante com $11 \%$ dos conceitos (TABELA 33).

A opinião da maioria dos atletas em achar extremamente importante a presença de um Cirurgião-Dentista na equipe acompanhando treinos e jogos, vem de encontro ao trabalho de FERREIRA ${ }^{31}$, onde foi publicado que 
"é essencial que o Cirurgião-Dentista que acompanha as competições possa atuar diretamente nos locais em que os atletas realizam suas provas, mesmo sem uso de radiografias, para determinar o futuro tratamento ou prognóstico dos traumas". Tal assertiva justifica-se plenamente ao final deste trabalho, dadas as observações realizadas em seu desenvolvimento, relacionadas às modalidades esportivas praticadas em Bauru que foram pesquisadas. 
7 CONCLUSÕES 



\section{CONCLUSÕES}

Com base na proposição formulada e na metodologia empregada, a partir dos resultados obtidos, pode-se concluir que:

1. Poucos atletas já sofreram traumatismo dentário ou apenas pancada durante a prática esportiva;

2. O protetor bucal usado pelos atletas é do tipo II (termo ajustável) adquirido em lojas de material esportivo.

3. Poucos esportistas faltaram aos treinos, jogos ou competições por causa de problemas dentários.

4. A maioria dos competidores é consciente que uma boca com problemas pode prejudicar a performance do atleta.

5. O dentifrício da preferência da maioria dos competidores é da marca Colgate, escolhido principalmente por seu sabor.

6. Um fator fundamental para melhorar o padrão de higiene bucal do atleta é levantar a sua auto-estima, conscientizandoo da importância da saúde bucal como um dos fatores 
indispensáveis à melhora do seu rendimento no esporte, visto que $33 \%$ dos entrevistados não freqüentam a clínica odontológica.

7. Um terço dos atletas recebeu informações de um CirurgiãoDentista, referentes à prevenção de traumatismos dentários, sugerindo que poucos profissionais possuem um conhecimento científico adequado sobre o assunto e se não conhecem impossibilita-os de atuarem corretamente no que se refere aos protetores bucais.

8. A maioria dos competidores acha extremamente importante à presença de um Cirurgião-Dentista em seus clubes acompanhando treinos, jogos e competições.

9. É imprescindível que se faça uma avaliação das condições de saúde bucal dos atletas no início de cada temporada esportiva e uma reavaliação a cada 6 meses.

10. No Brasil existe a necessidade de uma conscientização das instituições de saúde, educação e esportivas, para que sejam feitas campanhas públicas na tentativa de estimular os praticantes de esportes e a comunidade em geral a uma prática esportiva segura, utilizando protetores bucais durante 
as atividades esportivas e ensinando os procedimentos imediatos frente a um traumatismo dentário.

11. Novas pesquisas mais abrangentes devem ser realizadas, enfatizando as condições de saúde bucal de atletas amadores, profissionais e paraolímpicos de todas as modalidades esportivas. 
AneXos 
ANEXO 1

\begin{tabular}{|c|c|c|}
\hline 18 & \multicolumn{2}{|c|}{$\begin{array}{c}\text { UNIVERSIDADE DE SÃO PAULO } \\
\text { FACULDADE DE ODONTOLOGIA DE BAURU } \\
\text { Departamento de Odontopediatria, Ortodontia e Saúde Coletiva } \\
\text { Odontología Desportiva }\end{array}$} \\
\hline \multicolumn{3}{|c|}{ QUESTIONÁRIO } \\
\hline Idade: & & Data: / / \\
\hline Esporte: & ( ) Mas. ( ) Fem & ( ) Profissional ( ) Amador \\
\hline Cidade: & U.F.: & País: \\
\hline
\end{tabular}

1) Você já sofreu algum traumatismo dentário (perda ou fratura), praticando esporte?
( ) Nunca
( ) Apenas pancada
( ) Fratura
( ) Perda total de Dente(s)

2) Você conhece os protetores bucais? （ ) Sim （ ) Não

Em caso de resposta afirmativa responda as questões $\mathbf{a}, \mathbf{b}, \mathbf{c} e \mathbf{d}$ :
a. Você usa protetor bucal?
( ) Sim
( ) Não

b. De que tipo?

( ) Pré-fabricado (comprado em loja)

( ) Individualizado (feito por Cirurgião-Dentista)

( ) Unitário

( ) Duplo

c. Onde foi adquirido?

d. Alguma vez você usou um protetor bucal de um colega?
( ) Sim
( ) Não

3) Já deixou de treinar ou jogar por algum problema dentário?

( ) Sim ( ) Não

4) Você acha que a boca com problemas pode prejudicar a capacidade do atleta?

( ) Sim ( ) Não

5) O que você acha de seu clube ter um Cirugião-Dentista, acompanhando os treinos e jogos?
( ) Extremamente importante
( ) Pouco importante
( ) Importante
( ) Não precisa 


\section{Odontologia Desportiva}

Questionário de Avaliação

PADRÃO DE HIGIENE BUCAL e RELAÇÃO ATLETA / CIRURGIÃO-DENTISTA

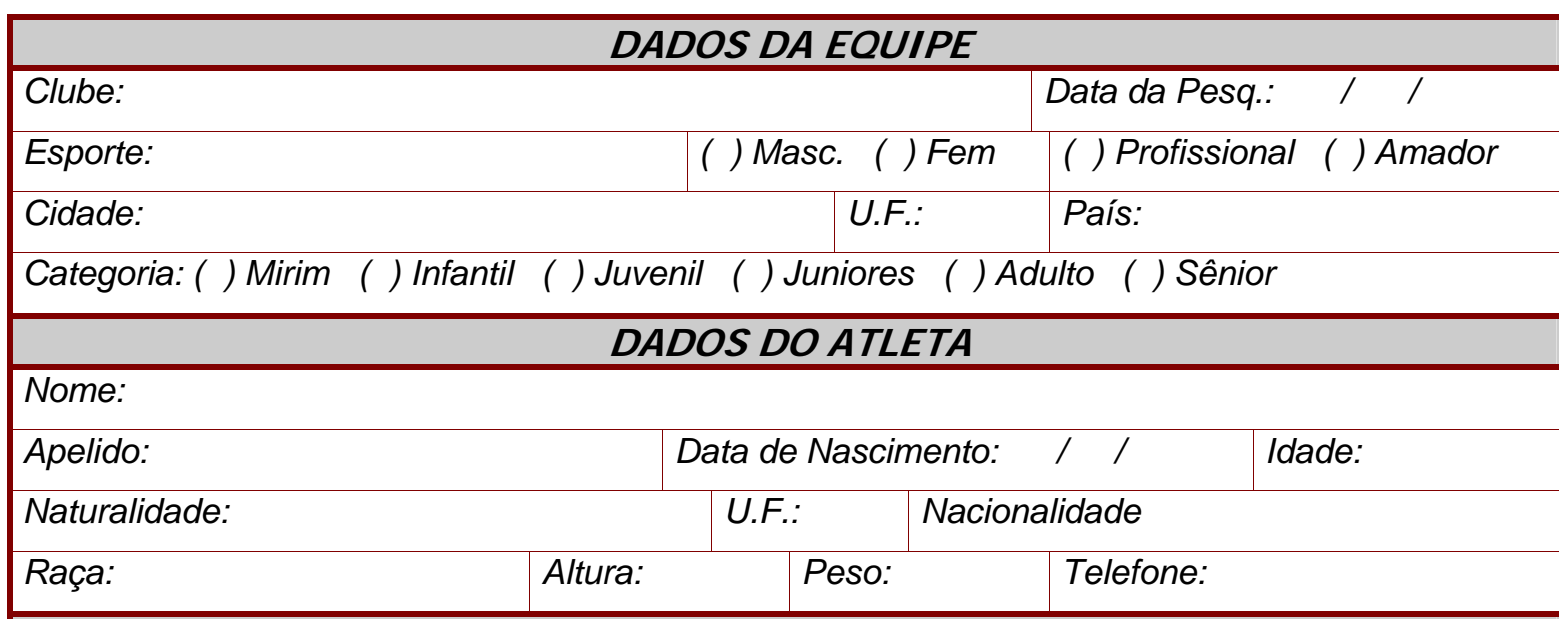

\section{PADRÃO DE HIGIENE BUCAL DO ATLETA}

Todas as pessoas que moram em sua residência usam o mesmo creme dental?

( ) Sim ( ) Não ( ) Outros:

É você quem compra seu creme dental?

( ) $\operatorname{Sim}$ ( ) Não Quem compra?

Você sempre usa o mesmo creme dental?

( ) $\operatorname{Sim}$ ( ) Não

Qual (is)?

Qual o principal motivo que o levou a escolher este creme dental?
( ) Sabor
( ) Perfume
( ) Maior disponibilidade no comércio
( ) Preço baixo
( ) Propaganda
( ) Indicação do Dentista
( ) Cor
( ) Consistência
( ) Outro
Qual (is)?

Quantas vezes você escova os dentes durante o dia?

( ) Uma () Duas ()Três ( ) Mais de três

Você seria capaz de identificar um creme dental somente pelo sabor?

( ) $\operatorname{Sim}$ ( ) Não Qual (is)?

Usa Fio Dental? （）Sim （）Não

Quantas vezes você passa fio dental durante o dia?

( ) Uma () Duas ( )Três ( ) Mais de três ( ) Não uso

Caso não use justifique.

( ) Não sei usar ( ) Acho ruim ( ) Não conheço ( ) Nunca Usei （）Preguiça 


\section{Usa algum bochecho em casa? () Sim ( ) Não}
S - Quantas vezes ao dia?
( ) Uma
( ) Duas
( )Três
( ) Mais de três

N-Por que?

( ) Nunca usei

( ) Não conheço

( ) Não Gosto

( ) Outro:

É você quem compra sua escova de dente?

( ) Sim ( ) Não Quem compra?

Qual a cor de sua preferência para uma escova de dente?
( ) Amarela
( ) Azul
( ) Branca
( ) Verde
( ) Vermelha
( ) Outra:

Qual o Tipo de escova você utiliza?
() Macia
( ) Extra-macia
( ) Média
( ) Dura
( ) Não sei

Você troca escova a cada:

( ) 1 Mês ( ) 2 Meses () 3 Meses () Mais de 3 meses

\section{RELAÇÃO ATLETA / CIRURGIÃO-DENTISTA}

Você tem medo de Dentista?

( ) $\operatorname{Sim}$ ( ) Não

Por que?

\section{Quem é que trata dos seus dentes?}

( ) Dentista PARTICULAR ( ) Dentista do CLUBE ( ) Dentista do SERVIÇO PÚBLICO

( ) Não vou ao Dentista. Por que?

Você visita o seu Dentista a cada:

( ) 1 Mês () 2 Meses () 3 Meses () 6 meses () 1 Ano () Mais de 1 ano

Qual o principal motivo que o levou a procurar um Cirurgião-Dentista?

( ) Mau hálito ( ) Traumatismo:

( ) Dor ( ) Sangramento $\quad$ ( ) Acho meus dentes feios

( ) Prótese ( ) Gosto de ir ao Dentista

( ) Outro:

Você já recebeu alguma informação de um Cirurgião-Dentista sobre prevenção de traumatismo dentário?

( ) $\operatorname{Sim}$ ( ) Não

O que você acha de seu clube ter um Cirurgião-Dentista, acompanhando os treinos e jogos?

( ) Extremamente importante ( ) Muito Importante ( ) Importante ( ) Desnecessário

( ) Não precisa 


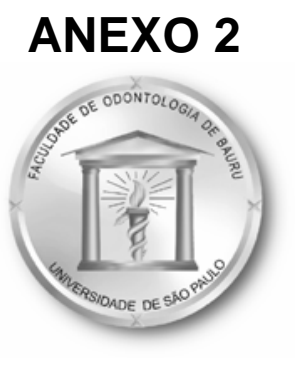

\section{Universidade de São Paulo}

Faculdade de Odontologia de Bauru

Al. Dr. Octávio Pinheiro Brisolla, 9-75 - Bauru-SP - CEP 17012-901

C.P. 73 PABX (0XX14)235-8000 - FAX (0XX14)223-4679

\section{CARTA DE INFORMAÇÃO AO SUJEITO DA PESQUISA}

Prezado Atleta:

Informo que será realizado um exame bucal em atletas amadores assistidos pela SEMEL (Secretaria de Esporte e Lazer) da cidade de Bauru-SP. Para isso vamos usar um impresso da Organização Mundial de Saúde para anotar se a pessoa tem algum problema bucal e, um questionário de Odontologia Desportiva onde as pessoas irão responder. Com isso vamos ter a possibilidade de verificar as condições de saúde bucal de atletas e servirá de base para o planejamento, execução, avaliação e reformulação de serviços de saúde bucal para as pessoas que praticam algumas atividades esportivas. Os participantes que serão examinados no levantamento não receberão qualquer tipo de tratamento de imediato, não havendo uso de materiais e equipamentos que venham por em risco à saúde dos mesmos. Haverá apenas inspeção em saúde bucal, com o uso de espelho clínico e sonda clínica da Organização Mundial de Saúde, denominada sonda CPI, com ponta (esférica)de aproximadamente 0,5mm, conforme recomendado eticamente em pesquisa.. Os dados serão usados em conjunto, não sendo, de forma alguma publicados individualmente em qualquer revista ou periódico de qualquer natureza. Os atletas envolvidos nesta pesquisa serão certificados sobre a possível presença de problemas bucais, orientados e, se possível encaminhados ao tratamento. Telefones para contato: 3235-8356 (Comitê de Ética e Pesquisa FOB-USP) e 9115-9161 (Hilton José Gurgel Rodrigues - Responsável).

Atenciosamente

Prof. Dr. José Roberto de Magalhães Bastos Orientador

Assinatura do Atleta ou

Responsável legal do menor

\section{TERMO DE CONSENTIMENTO LIVRE E ESCLARECIDO}

Pelo presente instrumento que atende às exigências legais, o Sr. portador da cédula de

identidade após leitura minuciosa da CARTA DE INFORMAÇÃO AO

SUJEITO DA PESQUISA, devidamente explicada pelos profissionais em seus mínimos detalhes, ciente dos serviços e procedimentos aos quais será submetido, não restando quaisquer dúvidas a respeito do lido e explicado, firma seu CONSENTIMENTO LIVRE E ESCLARECIDO concordando em participar da pesquisa proposta. Fica claro que o sujeito da pesquisa ou seu representante legal pode a qualquer momento retirar seu CONSENTIMENTO LIVRE E ESCLARECIDO e deixar de participar desta pesquisa e ciente de que todas as informações prestadas tornaram-se confidenciais e guardadas por força de sigilo profissional (Art. 9o do Código de Ética Odontológica).

Por estarem de acordo assinam o presente termo.

Bauru-SP 
Of.156/04=GS-SEMEL.

Bauru, 05 de maio de 2004.

Autorizo todos os atletas assistidos por esta Secretaria, participarem da pesquisa "AVAliaÇão DAS CONDiÇÕes DE SAÚE BUCAL DE ATLETAS AMADORES ASSISTIDOS PELA SEMEL (SECRETARIA DE ESPORTE E LAZER) DA CIDADE DE BAURU-SP, COM A UTILIZAÇÃO DO FORMULÁRIO ESPECÍFICO DA ORGANIZAÇÃO MUNDIAL DE SAÚDE E QUESTIONÁRIO DE ODONTOLOGIA DESPORTIVA", de autoria a responsabilidade do aluno de pós-graduação da Faculdade de Odontologia de Bauru — USP, Hilton José Gurgel Rodrigues, sob a orientação do Prof. Dr. José Roberto de Magalhães Bastos, nas modalidades esportivas que se fizerem necessárias.

\section{Atencigsamente}

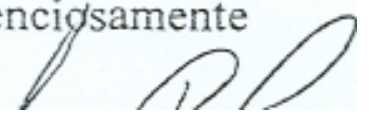

José Roberto Franco Secretário Municipal de Esportes e Lazer. 


\section{Universidade de Sao Paulo \\ Faculdade de Odontologia de Baum}

Al. Dr. Octavio Pinheiro Brisolla, 9-75 - Bauru-SP - CEP 17012-901 - G.P. 73

PABX (0)014)3235-8000 - FAX (0)0(14)3223-4679

Comite de 1 tica em 'ecquisa (323.5-6356)

Processo $n^{\circ}$ 62/2004

Bauru, 04 de outubro de 2004. Senhor Professor,

Informamos que após o envio da documentação pendente referente ao projeto de pesquisa encaminhado a este Comitê de Ética em Pesquisa "Avaliação das condições de saúde bucal de atletas amadores assistidos pela SEMEL (Secretaria de Esporte e Lazer) da cidade de Bauru-SP, com a utilização do formulário específico da Organização Mundial de Saúde e questionário de Odontologia Desportiva", de autoria do CD. Hilton Jose Gurgel Rodrigues, sob sua orientação foi novamente avaliado e considerado APROVADO por este Comitê em reunião realizada no dia 29 de setembro de 2004.

Lembramos que apos o envio do trabalho concluído, este Comitê enviara parecer final, que será utilizado para publicação do trabalho.

Atenciosamente,

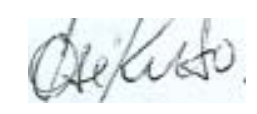

Prof Dr. José Henrique Rubo

Coordenador

$\mathrm{Ilm}^{\circ}$ Sr. Prof Dr. Jose Roberto de Magalhaes Bastos

DD. Docente do Departamento de Odontopediatria, Ortodontia e Sande Coletiva 


\section{Universidade de Sao Paulo}

Faculdade de Odontologia de Bauru

Al. Dr. Octavio Pinheiro Brisolla, 9-75 - Bauru-SP - CEP 17012-901 - C.P. 73 PABX (OXXI4)3235-8000 - FAX (OXX14)3223-4679

Comitê de Ética e Pesquisa (3235-8356)

Of. ${ }^{\circ}$ CEP/23 2005/ FOB

Senhor Professor,

Conforme sua solicitação referente a modificação de titulo do trabalho de pesquisa aprovado em 29 de setembro de 2004, intitulado "Avaliação das condições de saúde bucal de atletas amadores assistidos pe/a SEMEL (secretaria de Esporte e Lazer) da cidade de Bauru-SP, corn a utilização do forrnulário específico da Organização Mundial de Saúde e questionário de Odontologia Desportiva de autoria do CD. Hilton Jose Gurgel Rodrigues, desenvolvido sob orientação, informamos que apos analise autorizamos a alteração para o titulo "Padrão de conhecimento do atleta amador de Bauru-SP, em relação aos cuidados de saúde bucal", considerando não ter modificado a metodologia proposta.

Lembramos que apos o envio do trabalho concluído, este Comitê enviara o parecer final, que será utilizado para a publicação do trabalho.

Atenciosamente,

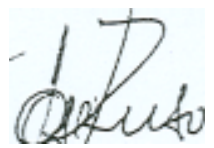

Prof. Dr. José Henrique Rubo

Coordenador do Cornitê de Ética em Pesquisa

$\mathrm{IIm}^{\circ}$ Sr. Prof. Dr. J osé Roberto de Magalhães Bastos

DD. Docente do Departamento de Odontopediatria, Ortodontia e Saúde Coletiva 
REFERENCIAS BIBLIOGRÁFICAS 


\section{REFERÊNCIAS BIBLIOGRÁFICAS}

1. ABRAHAM, N.J.; CIRINCIONE, U.K. \& GLASS, R.T. - Dentists' and dental hygienists' attitudes toward toothbrushes replacement and maintenance. Clin Prev Dent, v.12, n.5, p.28-33, Dec. 1990.

2. AMERICAN DENTAL ASSOCIATION. Mouth protectors and sports team dentists. J Am Dent Assoc, v.109, n.1, p. 84-7, July 1984.

3. AMORIM, V.C.S.A. Visão que a criança tem do dentista através da interpretação de desenhos: um feedback para o profissional. Camarajibe, 1994. 168p. Dissertação (Mestrado) - Faculdade de Odontologia, Universidade de Pernambuco.

4. ANDRADE, M. de. A odontologia entra em campo. Rev Assoc Bras Odonto, v.4, n.2, p.76-80, abr./mai. 1996.

5. ANDREASEN, J.O.; ANDREASEN, F.M. Lesiones traumáticas de los dientes. 3.ed. Barcelona, Labor, 1984.

6. ANDREASSEN, J.O.; ANDREASSEN, F.M. Traumatismo dentário: soluções clínicas. São Paulo, Panamericana, 1991. 
7. APCD. CDs debateram Odontologia Desportiva. J Assoc Paul Cir Dent, n. 538, p. 60, fev. 2002.

8. APCD. O elo entre a odontologia e o conhecimento do esporte. Disponível na Internet. http://www.apcd.org.br/Biblioteca/Jornal/2001/08/elo.asp. 15 out. 2002.

9. ARAÚJO, C.S.; CORMACK. E.F. Odontologia Desportiva: Atendimento odontológico aos jogadores das Seleções Brasileiras de Futebol. J Assess Prestação Serv Odont, v.2, n.11, p. 28-9, nov./dez. 1998.

10. ARAÚJO, C.S.; CORMACK. E.F. Odontologia Desportiva. Disponível na Internet. http://campus.fortunecity.com/aurora/496/luc3e.html 30 mar. 2002

11. ARAÚJO, M.A.M. Tratamento clínico dos traumatismos dentários. 1.ed. São Paulo, Santos, 1999. Cap.1, p.1-22.

12. BARBERINI, A.F. Avaliação da influência do uso de diferentes tipos de protetores bucais no rendimento físico de atletas. São Paulo, 2003. 96p. Dissertação (Mestrado) - Faculdade de Odontologia, Universidade de São Paulo. 
13. BARBERINI, A.F.; AUN, C.E.; CALDEIRA, C.L. Incidência de injúrias orofaciais e utilização de protetores bucais em diversos esportes de contato. Rev Odontol UNCID, v.14, n.1, p.7-14, jan./abr. 2002.

14. BARROS, L.F.P de; LOPES, C.; O uso do midazolam via oral em cirurgia ambulatorial: relato de dois casos clínicos. Rev Bras Cir Protese Implant, v.10, n.38, p.169-73, abr.jun. 2003.

15. BIJELLA, M.F.T.B. el al. Occurrence of primary incisor traumatism in Brazilian children: house-by-house survey. J Dent Child., v.57, n.6, p.424-7, Nov./Dec. 1990.

16. BOMFIM, A.R.; COIMBRA, M.E.R.; MOLITERNO, L.F.M. O potencial erosivo dos repositores hidroeletrolíticos sobre o esmalte dentário: Revisão de literatura. Rev Bras Odontol, v.58, n.3, p.164-8, mai./jun. 2001.

17. BUISCHI, Y. Bebidas e alimentos ácidos causam erosão dentária. Disponível na Internet. http//www.odontologia.com.br.asp?id=366idesp=1\&ler=s 22 mar. 2004.

18. CANTO, G. de L. et al. Protetores bucais: uma necessidade dos novos tempos. Rev dent press ortodon ortoped facial, v.4, n.6, p.20-6, 
nov./dez. 1999.

19. CAVEZZI JUNIOR, O. et al. Efeitos de bochechos de clorexidina na saúde gengival em pacientes portadores de aparelhos ortodônticos. Periodontia, v.5, n.3, p.309-11, jan./jun. 1996.

20. CHANDRA, S. Sports dentistry - 2000. Disponível na Internet. http://www.schandra.8m.com/sports dentistry 21 fev. 2004.

21. CHAPMAN, P.J. The prevalence of orofacial injuries and use of mouthguards in rugby union. Aust Dent J, v.30, n.5, p.364-7, Oct. 1985.

22. CHELOTTI, A.; VALENTIM, C. Lesões traumáticas em dentes anteriores. In: GUEDES PINTO, A.C. Odontopediatria. 1.ed. São Paulo, Santos, Cap.35, p.771-98, 1988.

23. CRITCHLEY, G.R.; MANNION, S.; MEREDITH, C. Injury rates in Shotokan Karate. Br J Sports Med, v.33, n.3, p.174 -7, June. 1999.

24. DAVIS, M.J. Orofacial trauma management. N Y State Dent J, v. 61, n.7, p. 42-6, Aug./Sept. 1995.

25. DE WET, F.A. The prevention of orofacial sports injuries in the 
adolescent. Int Dent J, v.31, n.4, p.313-9, Dec. 1981.

26. DE YOUNG, A.K.; ROBINSON, E.; GODWIN, W.C. Comparing comfort and wearibility: custom-made vs. self-adapted mouthguards. J Am Dent Assoc, v.125, n.8, p.1112 -8, Aug. 1994

27. DIAB, N.; MOURINO, A.P. Parental attitudes toward mouthguards. Pediatr Dent, v.19, n.8, p.455-60, Nov./Dec. 1997.

28. DREYER, R. Mouth protectors, trauma care top sport dentistry agenda. Dent Stud, v.62, n.4, p.12-5, Jan. 1984.

29. EPSTEIN, L.I., Traumatic injuries to anterior teeth in the children. Oral Surg Oral Med Oral Pathol, v. 15, n. 3, p. 334-44, Mar. 1962.

30. FERRARI, C.H.; SIMI Jr., J.; MEDEIROS, J.M.F de. Ocorrência de traumatismo dental e nível de esclarecimento e uso do protetor bucal em diferentes grupos de esportistas. Disponível na Internet. http://www.odontologia.com.br/artigos.asp?id=88\&idesp=2\&ler=s 1 mai. 2002.

31. FERREIRA, R. A. Impacto radical. Rev Ass Paul Cir Dent, v.52, n.4, p.265-71, jul./ago. 1998. 
32. FLANDERS, R.A. Mouthguards and sports injuries. III Dent J, v.62, N.1, p.13-6, Jan./Feb. 1993.

33. FLANDERS, R.A. Project mouthguards. III Dent J, v.64, n.2, p. 67-9, Mar./Apr. 1995.

34. FUTAKI, J.; MOTTA, L.F.G. Protetores bucais: promoção da saúde na odontologia. Rev Odontol Univ St Amaro, v.5, n.2, p.98-105, jul./dez. 2000.

35. GARON, M.W.; MERKLE, A.; WRIGHT, J.T. Mouth protectors and oral trauma: a study of adolescent football players. J Am Dent Assoc, v.112, n.5, p.663-5, May. 1986.

36. GLASSMAN, M. The first line of defense. N Y State Dent J, v.61, n.7, p.48-50, Aug./Sept. 1995.

37. GODDEN, L.J. The importance of mouthguards. Br Dent J, v.120, n.9, p.399, May 1966.

38. HAMILTON, F.A.; HILL, F.J.; MACKIE, I.C. Investigation of lay knowledge of the management of avulsed permanent incisors. Endod Dent Traumatol, v.13, n.1, p.19-23, Feb. 1997. 
39. HICKEY, J.C. et al. The relation of mouth protectors to cranial pressure and deformation. J Am Dent Assoc, v.74, n.4, p.735-40, Mar. 1967.

40. HIDASI, G.; TARJAN, I.; CSOROGI I. About injuries to primary teeth. J Int Assoc Dent Child, v.17, n.2, p.77-80, Dec. 1986.

41. HOLMES, C. Mouth protection in sport in Scotland - a review. Br Dent $\mathbf{J}$, v.188, n.9, p.473-4, May 2000.

42. JALLEH, G. et al. Increasing mouthguards usage among junior rugby and basketball players. Aust N Z J Public Health, v.25, n.3, p.250-2, Sep. 2001.

43. JOHNSEN, D.C.; WINTERS J.E. Prevention of intraoral trauma in sports. Dent Clin North Am, v.35, n.4, p.654-66, Oct. 1991.

44. JOHNSON, J.E. Causes of accidental injuries to primary teeth and jaws. J Public Health Dent, v.35, n.2, p.123-31, Spring 1975.

45. JOHNSON \& JOHNSON. Brasileiro demoraria até 17 meses para trocar escova de dentes. Disponível na Internet. http://www.odontologia.com.br/noticias.asp?id=594\&idesp=1\&ler=s 14 ma. 2005. 
46. JOLLY, K.A.; MESSER, L.B.; MANTON, D. Mouthguard protection in spots injuries. Aust Dent J, v.40, n.6, p.399, Dec. 1995.

47. JOSELL, S.D.; ABRAMS, R.G. Traumatic injuries to the dentition and its supporting structures. Pediatr Clin North Am, v.29, n.3, p.717-41, June 1982.

48. KALINA, S. Give teeth a sporting chance. Pa Dent J, v.62, n.1, p.13-6, Jan./Feb. 1995.

49. KONIS, A.B. Treatment of a traumatic tooth avulsion. N Y State Dent J, v.61, n.7, p 39-41, Aug./Sept. 1995.

50. KUMAMOTO, D.P. et al. Tooth avulsions resulting from basketball net entanglement. J Am Dent Assoc, v.128, n.9, p1273-5, Sep. 1997.

51. KUMIYAMA, E.Y.; KOGA-ITO, C.Y. Eficiência em foco. Disponível na Internet. http://www.unesp.br/noticias/280504a.php 28 mai. 2004.

52. LANCASTER, D.J.; RANALLI, D.N. Comparative evaluation of college football official's attitudes toward NCAA mouthguard regulations and player compliance. Pediatr Dent, v.15, n.6, p.398-402, Nov./Dec. 
1993.

53. LASKIN, D.M. Protecting faces of America. J Oral Maxill Surg, v.58, n.4, p.363, Apr. 2000.

54. LIMA, I.C. A importância do Cirurgião-Dentista na seleção brasileira de futebol. J Ass Paul Cir Dent, n. 542, p.22-3, jun. 2002.

55. LIMA, I.C. A odontologia exercida nos clubes de futebol. J Ass Paul Cir Dent, n. 546, p.26-7, out. 2002.

56. MAESTRELLO, C.L.; MOURINO, A.P; FARRINGTON, F.H. Dentists' attitudes toward mouthguards protection. Pediatr Dent, v.21, n.6, p.340-6, Sept./Oct. 1999.

57. MAESTRELLO-DE-MOYA, M.G.; PRIMOSCH, R.E. Orofacial trauma and mouth-protector wear among high school varsity basketball players. J Dent Child, v.56, n.1, p.36-9, Jan./Feb. 1989.

58. MC NUTT. T. et al. Oral trauma in adolescent athletes: a study of mouth protectors. Pediatr Dent, v.11, n.3, p.209-13. Sep. 1989.

59. NATIONAL YOUTH SPORTS SAFETY FOUNDATION. Sports dentistry facts: facts from the National Youth Sports Foundation for Safety. 
Disponível

na

Internet.

http://www.qualitydentistry.com/dental/sdentistry/s-dent.html 08 mai 2002.

60. NICHOLAS, N.K. Mouth protection in contact sports. N Z Dent J, v.65, n.299, p.14-24, Jan. 1969.

61. NORONHA, J.C. et al. Parâmetros clínicos para classificação do estado motivacional familiar em odontopediatria. J Bras Odontopediatr Odontol Bebe, v.4 n.17, p.63-67, jan./fev. 2001.

62. NOVICH, M.; SCHWARTZ, R. The athlete's mouthpiece. Clin Prev Dent, v.7, n.3, p.8-21, May/June, 1985

63. OLIVEIRA, M.B.R.G.de. Novo campo para a odontologia. ROBRAC, v.9, n.27, p.30-1, jun. 2000.

64. PADILLA, R.; PICCININNI, P. What is Sports Dentistry? Disponível na Internet. http://www.sportsdentistry.com/sportsdentistry.html 10 mar. 2003

65. PANZERI, H. et al. Descoloração de cerdas impregnadas com corantes como medida da durabilidade de escovas dentais. Rev Assoc Bras Odont, Ed. Especial, v.2, p.33-9, jan. 1994. 
66. PAVARINI A.; GARIB, T.M. Prevenção de traumatismos buco-dentários. RGO., v.41, n.1, p.41-4, jan/fev. 1993

67. PRIETO, G.B.; DAVIDOWICZ, H.; MOURA, A.A.M. Métodos preventivos frente aos traumas dentários. Rev Inst Ciênc Saúde, v.14, n.1, p.335, jan./jun. 1996.

68. PRIETO, G.B.; DAVIDOWICZ, H.; MOURA, A.A.M. Protetor bucal -1. Rev Inst Ciênc Saúde, v.16, n.1, p.61-3, jan./jun. 1998.

69. PRIETO, G.B.; DAVIDOWICZ, H.; MOURA, A.A.M. Protetor bucal -2. Rev Inst Ciênc Saúde, v.16, n.2, p.99-102, jul./dez. 1998.

70. QUINN, N.W. Australian rules football injuries. Aust Fam Physician, v.12, n.9, p.691-2, 694, Sept. 1983.

71. RANALLI, D.N. Preventing mouth injuries during sports. Pa Dent J, v.62, n.1, p.17-20, Jan./Feb. 1995.

72. RANALLI, D.N.; LANCASTER, D.M.. Attitudes of college football officials regarding NCAA mouthguard regulations and player compliance. J Public Health Dent, v.55, n.3, p.139-42, Summer 1995. 
73. RIBEIRO, A.A.; GUEDES, R.S.; SOUZAI.P.R. Recuperação da confiança do atleta com o uso de protetores bucais na prática de esportes. J Bras Odontopediatr Odontol Bebe, v.5, n.23, p.11-5, jan./fev. 2002.

74. RODRIGUES, A.M.; RODRIGUES, R.M. O mergulho e a odontologia. J Assess Prestação Serv Odont, n. 21, p. 17-9, 2000.

75. RODRIGUES, H.J.G. Odontologia Desportiva. Bauru, 2003. 53p. Monografia (Especialização) - Associação Paulista de CirurgiõesDentistas.

76. RODRIGUES, H.J.G.; SALES PERES, A.; BASTOS, J.R. de M. Odontologia Desportiva: Perspectivas Profissionais do Cirurgião Dentista Para o Atleta. Revisão da literatura. In: JORNADA ODONTOLÓGICA DE BAURU "PROF. LUIZ FERNANDO PEGORARO", 15., Bauru, 2002. Anais.

77. SANE, J.; YLIPAAVALNIEMI, P. Dental trauma in contact team sports. Endod Dent Traumatol, v.4, n.4, p. 164-9, Aug. 1988.

78. SCAPINI, C. A importância da saúde oral no condicionamento físico do atleta profissional e do atleta amador. Disponível na Internet http://www.abop.pt/artigos/artigo junho 2004.htm 1 ago. 2004. 
79. SOUZA, E.R. Odontologia desportiva. Disponível na Internet. http://www.acdssv.com.br/revista/artigos cientif/01 03 2004.htm. 1 ago. 2004.

80. STEVENS, O.O. Mouth Protectors: evaluation of twelve types - second year. J Dent Child, v.32, n.3, p.137-43, July/Aug./Sept. 1965.

81. TANAKA, N. et al. A etiology of maxillofacial fracture. $\mathbf{B r} \mathbf{J}$ Oral Maxillofac Surg, v.32, n.1, p.19-23, Feb. 1994

82. TUMENAS, I. Orientando o paciente: escovas dentais. Disponível na Internet.http://www.apcd.org.br/Biblioteca/Revista/1999/jul ago 99/3 07.asp 1 ago. 2004.

83. VELASCO, L.F.L; MUNHOZ, M.F. Odontologia desportiva - proteção bucal na prevenção de traumatismos dentários. Disponível na Internet. http://www.dentalplanet.com.br/odontologia desportiva.asp 30 Jun. 2002.

84. WIJN Jr., V.M.M. de et al. A mechanical investigation of the functioning of mouthguards. In: HIUSKES, R. et al. ed. Biomechanics: principles and application. Loncken Martinus Mijhoff, p.451-458,1982. 
ABSTRACT 


\section{ABSTRACT}

This work aimed at evaluating the knowledge standards of amateur athletes in the city of Bauru, SP, regarding oral health care such as: prevention of dental traumatism, brushing, flossing, most used dentifrice, use of mouthwashes and toothbrushes utilized. Furthermore, the habit and frequency of dental appointments, both in public and private practice, were evaluated. A questionnaire was elaborated and applied in a sample of 36 athletes, being 15 male and 21 female, aged 16 - 28 years, all members of amateur teams assisted by SEMEL (Secretaria Municipal de Esporte e Lazer), in the following modalities: boxing, capoeira, soccer and volleyball. By analyzing the results, it was concluded that the athletes, even without the knowledge considered ideal in terms of oral hygiene, and regarding the relation oral health with general health, in their majority are aware that a mouth with problems can upset his/her performance and think that it is extremely important that a dental surgeon, in their teams, follow the training, games and competitions. Nevertheless, only $17 \%$ of the athletes use oral protectors during sportive practices, $64 \%$ brush their teeth three times a day, $50 \%$ use the dental floss, $44 \%$ perform mouthwashes and $33 \%$ do not go to the dental clinic, being pain the main factor why sportsmen look for it. These evidences reflect not only a local, but a Brazilian reality, which corroborate the need of awareness by

health, educational and sportive institutions, for public campaigns to be carried out, in an attempt to stimulate those who practice sports and the community, in general, to pay closer attention to oral hygiene, to practice sports in a safe way, utilizing oral protectors, and teaching the immediate procedures, in the event of a dental traumatism. 
RESUMEN 


\section{RESUMEN}

El presente estudio tiene como objetivo evaluar el padrón de conocimientos de los atletas amateurs de la ciudad de Bauru-SP, relacionado con los cuidados de la salud bucal, así como: prevención de los traumatismos dentales, cepillado, uso de hilo dental, dentrificos mas usados y uso de enjuagues y cepillos mas utilizados. Además de eso, también fue evaluado el habito y la frecuencia de las consultas odontológicas, en el sector publico y privado. Fue elaborado un cuestionario y aplicado a una muestra de 36 atletas, siendo 15 del sexo masculino y 21 del sexo femenino, todos miembros de equipos amateurs apoyados por la secretaria municipal de deportes y esparcimiento (SEMEL), de las modalidades de box, capoeira, fútbol y voleibol, con una edad media entre 16 y 28 años. El análisis de los resultados permitió evidenciar que los atletas, aun sin los conocimientos considerados como ideales de la higiene bucal y de la salud bucal como la salud general, en su mayoría fueron concientes que una boca con problemas puede perjudicar el desempeño del atleta y consideran importante la asistencia de un Cirujano Dentista en sus equipos, acompañándolos en sus entrenamientos, juegos y competiciones. Sin embargo solo $17 \%$ de los atletas usan protectores bucales durante la practica deportiva, 64\% cepillan sus dientes tres veces al día, 50\% usan hilo dental, 44\% realizar enjuagues y 33\% no asisten a la clínica odontológica, siendo el dolor la principal razón que lleva a los deportistas a acudir al Cirujano Dentista. Estos resultados reflejan una realidad no solo local, sino también brasileña y comprueba la necesidad de una concientización de las instituciones de salud, educativas y deportivas, para que se realicen campañas publicas con el objetivo de estimular a las personas que practican deporte y a la comunidad en general a una mejor atención para los ciudadanos de la higiene bucal, practicar deporte con protección, utilizando protectores bucales, y enseñar los procedimientos básicos de urgencia frente a un traumatismo dentario. 


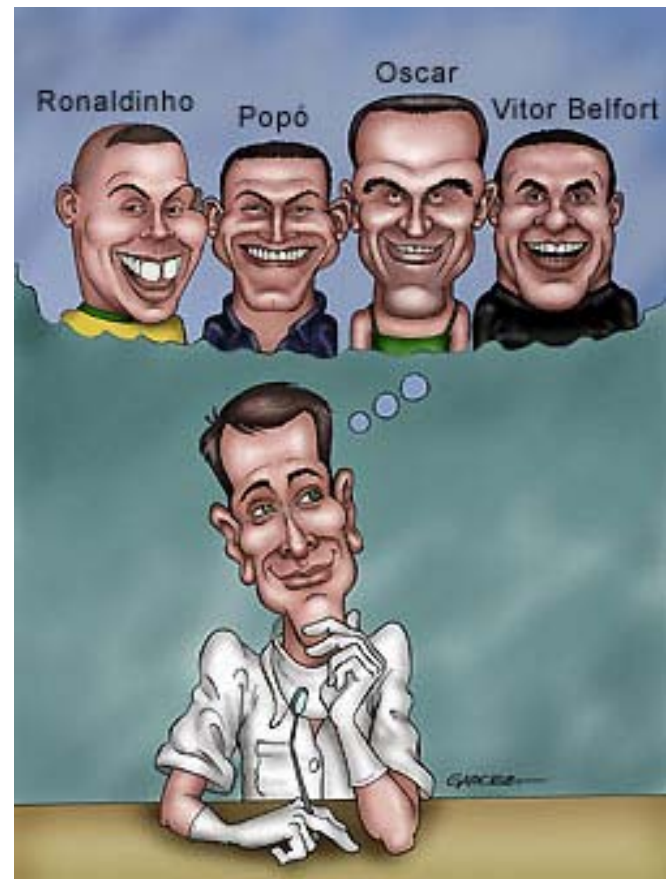

“Um sonho sonhado só é só um sonho.

Mas, um sonho sonhado por muitos, pode tornar-se realidade”. 